\title{
At the Crossroads of Textile Cultures: Textile Production and Use at the South Italian Archaic Site of Ripacandida
}

\author{
Margarita Gleba ${ }^{1}$, Christian Heitz ${ }^{2}$, Hedvig Landenius Enegren ${ }^{3}$ and Francesco $\mathrm{Meo}^{4}$ \\ ${ }^{1}$ McDonald Institute for Archaeological Research, University of Cambridge, Downing Street, Cambridge \\ CB2 3ER, UK \\ E-mail: mg704@cam.ac.uk
}

${ }^{2}$ Institut für Archäologien, University of Innsbruck, Langer Weg 11, A-6020 Innsbruck, Austria

E-mail: Christian.Heitz@uibk.ac.at

${ }^{3}$ Centre for Textile Research (CTR), University of Copenhagen, Saxo Institute, Karen Blixens Plads 8, DK2300 Copenhagen, Denmark

E-mail: hedvigenegren@gmail.com

${ }^{4}$ Dipartimento di Beni Culturali, Università del Salento, Via Dalmazio Birago 64, 73100 Lecce, Italy

E-mail: francesco.meo@unisalento.it

\begin{abstract}
Textiles are seldom included within socioeconomic interpretative frameworks of the ancient northern Mediterranean region, although several recent studies have begun to address this lacuna. The Archaicl Classical site of Ripacandida (Basilicata), located in the southern Apennines, has yielded both textiles and textile tools, providing an unprecedented opportunity to examine textile production and use at an indigenous south Italian site. This study presents the results of the complementary analyses of mineralised textile remains and textile tools (spindle whorls and loom weights) found in the cemetery of Ripacandida. The unusual combination of the Greek textile weave (weft-faced tabby) and a characteristic Italic tablet-woven border in two fragments attests to a mixed textile culture. The (to date) unique situation at Ripacandida enables us to reflect on the role of textiles in cultural contact contexts: the way in which textile cultures and their elements met and were mixed or kept separate in south Italy and beyond; the extent to which textile production was socially and economically embedded in a small indigenous community of south Italy; and the role of textiles and textile production as an expression of indigenous-Greek interaction.
\end{abstract}

Keywords: Archaic southern Italy, Italic-Greek interaction, loom weight, Ripacandida, spindle whorl, textile

\section{Introduction}

Textiles represent a category of material little known to the general archaeological audience. The perishable nature of textile remains in the archaeological record has undoubtedly contributed to the silence of textile technol-

(C) Equinox Publishing Ltd., 2018 ogy as a major cultural, economic and social component of the Mediterranean past. Textiles, however, are more common in archaeological contexts than generally thought, and recent research has thrown new light on the textile cultures of Italy and their relations to central https://doi.org/10.1558/jma.36808 
Europe, Greece and the Near East during the first millennium BC (Gleba 2017b). In this paper, we demonstrate the type of information that can be inferred from a detailed analysis of ancient textile remains and of the tools used in their manufacture, and the significance such an analysis has in providing insight into cultural encounters and the resulting mixed expressions that (may) occur.

South Italy was an arena for complex interactions between the indigenous and Greek cultures during the greater part of the first millennium BC (see e.g. Donnellan et al. 2016). The complexity and local variability of economic and cultural contacts between the diverse communities led to various degrees of interaction. Over the last two decades, scholars have moved away from a model of Hellenisation, mediated largely by the Graeco-Roman written sources, towards postcolonial concepts of cultural interactions such as hybridisation (van Dommelen 2005; 2011; for current debate on hybridisation, see e.g. Liebmann 2013; Silliman 2015). In material culture, a mix of styles or techniques and influences has been observed most notably in pottery, architecture, settlement and cemetery patterns.

Textiles present a special case in the production system of ancient south Italy. For millennia, most households produced cloth on a small scale for their own consumption. The social changes brought about during the early first millennium BC heralded the development of luxury and surplus textile production on a larger and/or more specialised scale (Gleba 2008: 189-94; Quercia and Foxhall 2014: 69). The foundation of Greek colonies led to the arrival of new techniques and even a new textile culture (Meo 2015: 41-54; Gleba 2017b). Given the importance of textiles in creating individual and group identities through direct interaction with a human body, and at the same time acknowledging the conservative nature of the textile craft, how did these new techniques affect the local status quo?
At Ripacandida, a site recently studied with special attention to the social development of the community (Heitz 2016; 2018), the textile remains and tools were recovered from the well-documented burial contexts of a small indigenous community. They are directly associated with individuals who faced a situation of intercultural contact, as witnessed by their equipment, which included Greek or Greekinspired objects, such as pottery. The site provides an unprecedented opportunity to reflect on the role of textiles and textile production in cultural contact contexts as an expression of a 'materiality of interaction' (Donnellan 2016: 12; see also van Dommelen and Knapp 2010) that resulted from the mixing of indigenous and Greek textile cultures.

In this paper, we present the archaeological context and results of the detailed technical analyses of textiles and textile tools from Ripacandida, which are then considered within the broader gamut of south Italian evidence and Mediterranean textile cultures. Finally, we interpret textile production and consumption at Ripacandida in light of Greek-indigenous interaction in south Italy.

\section{The Site of Ripacandida}

Ripacandida is situated in the Melfese, a mountainous hinterland area in south Italy, present-day Basilicata (Figure 1). It occupies a central spot that oversees the junction of the small river valleys of the Calcinara and other tributaries to the Ofanto (Carollo and Osanna 2009: 394). These river valleys, together with the source of the Sele River, formed a trans-Apennine axis between the Tyrrhenian and the Adriatic Seas, whilst the valleys of the Bradano and Basento rivers connected the inland areas to the Ionian coast, suggesting the area may have served as a crossroads (Bottini 1982: 152; Bianco 1999: 142).

An indigenous Italic community used the burial ground from the end of the seventh to the end of the fifth century BC. The excavated 


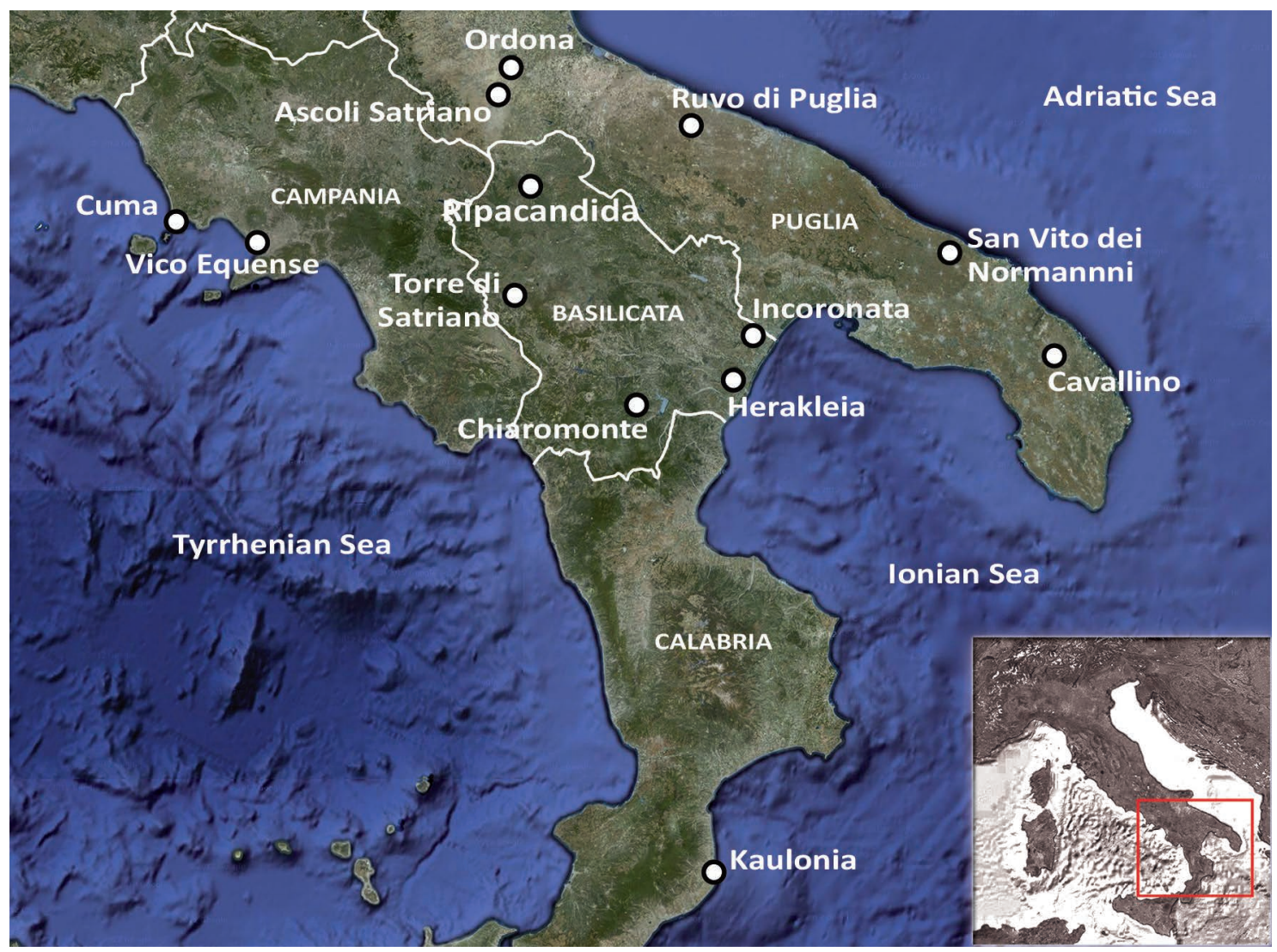

Figure 1. Map of south Italy with sites mentioned in text indicated (image: F. Meo).

parts of the cemetery, uncovered in the late 1970 s and 1980s, consist of 134 tombs located on the fringes of the modern town (Bottini $1978 ; 1979 ; 1980)$. The analysis of the cemetery was recently completed by one of the present authors (Heitz 2015; 2016; 2018). Regrettably, settlement evidence contemporaneous with the cemetery is lacking. Limited archaeological finds indicate the presence of wells before (eighth to seventh century BC) and some settlement traces after (fourth century BC) the use of the area as a cemetery (Carollo and Osanna 2009: 394-409).

The construction of the graves is, in most cases, very simple and consists of roughly rectangular pits containing inhumations (Figure 2). Marked differences concern mostly their depth and are probably connected to the age of the deceased, the graves of adults being generally deeper than those of children. In some of the graves, the floor is paved with stones (Figure 3) and in a few cases the construction of a 'sarcophagus' of stone slabs or the alignment of the tomb walls with stones was observed, while in several tombs, the excavators found traces of wooden coffins.

The dead were placed in a crouched position with stretched spine and the legs strongly bent, a position that is very common for indigenous Archaic inhumations in the eastern part of the south Italian peninsula (Scalici 2009; Heitz 2018). Unfortunately, the skeletal material was subsequently lost and is therefore not available for anthropological study, making gender assignment of specific individuals impossible. 


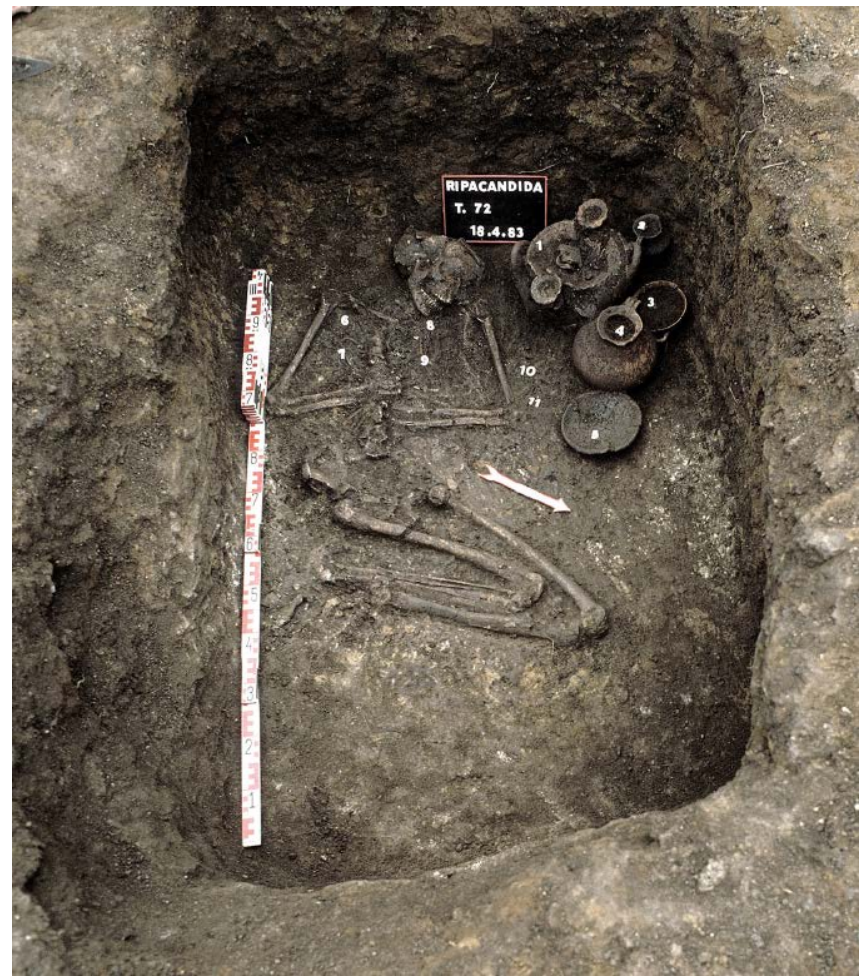

Figure 2. Ripacandida Tomb 72, a simple pit with inhumation and ceramic grave goods (image: Soprintendenza per i Beni Archeologici della Basilicata).

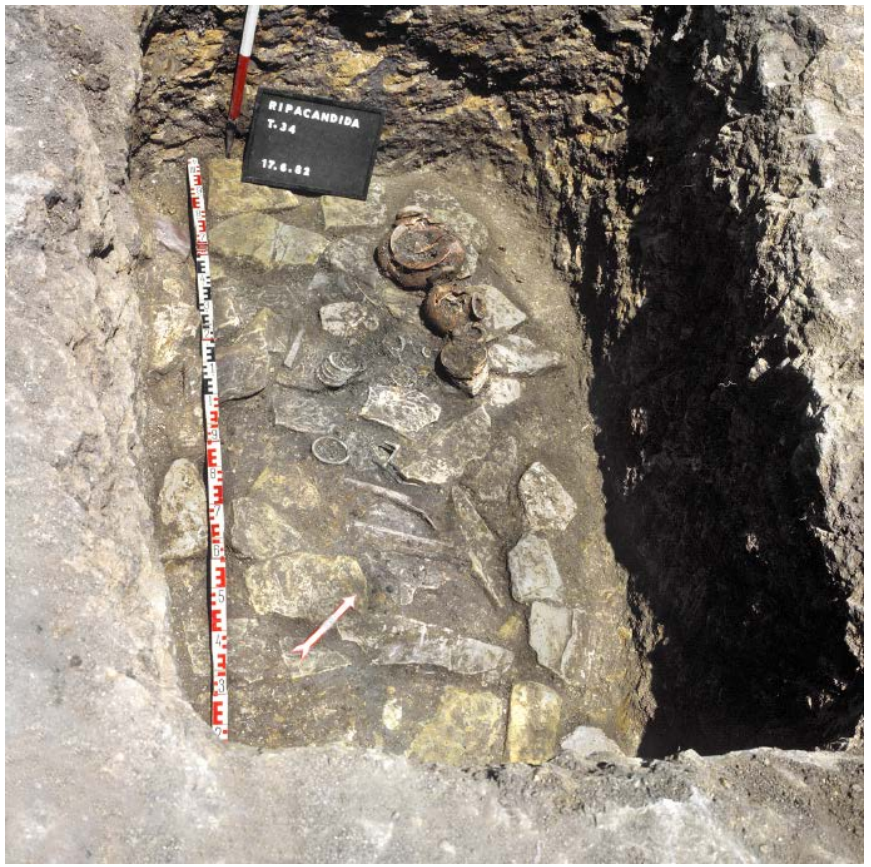

Figure 3. Ripacandida Tomb 34, a fossa inhumation paved with stone slabs (image: Soprintendenza per i Beni Archeologici della Basilicata). 


\section{Burials and Their Grave Goods}

The graves are organised in clusters, probably corresponding to families or households (Figure 4). Almost every cluster includes adults and children. The grave goods attest to the wide networks of this small community: apart from locally made pottery, there are vessels that were clearly procured from indigenous workshops farther east (Daunia), southeast (Apulia) and southwest (Campania), but also pottery of Greek type produced either in the colonies or in their vicinity, or imported from the Greek mainland (Setari 1999; Heitz 2018). Pottery and fibulae form part of nearly all assemblages. Weapons seem to be regularly associated with corpses deposited on their right side, whereas textile tools such as
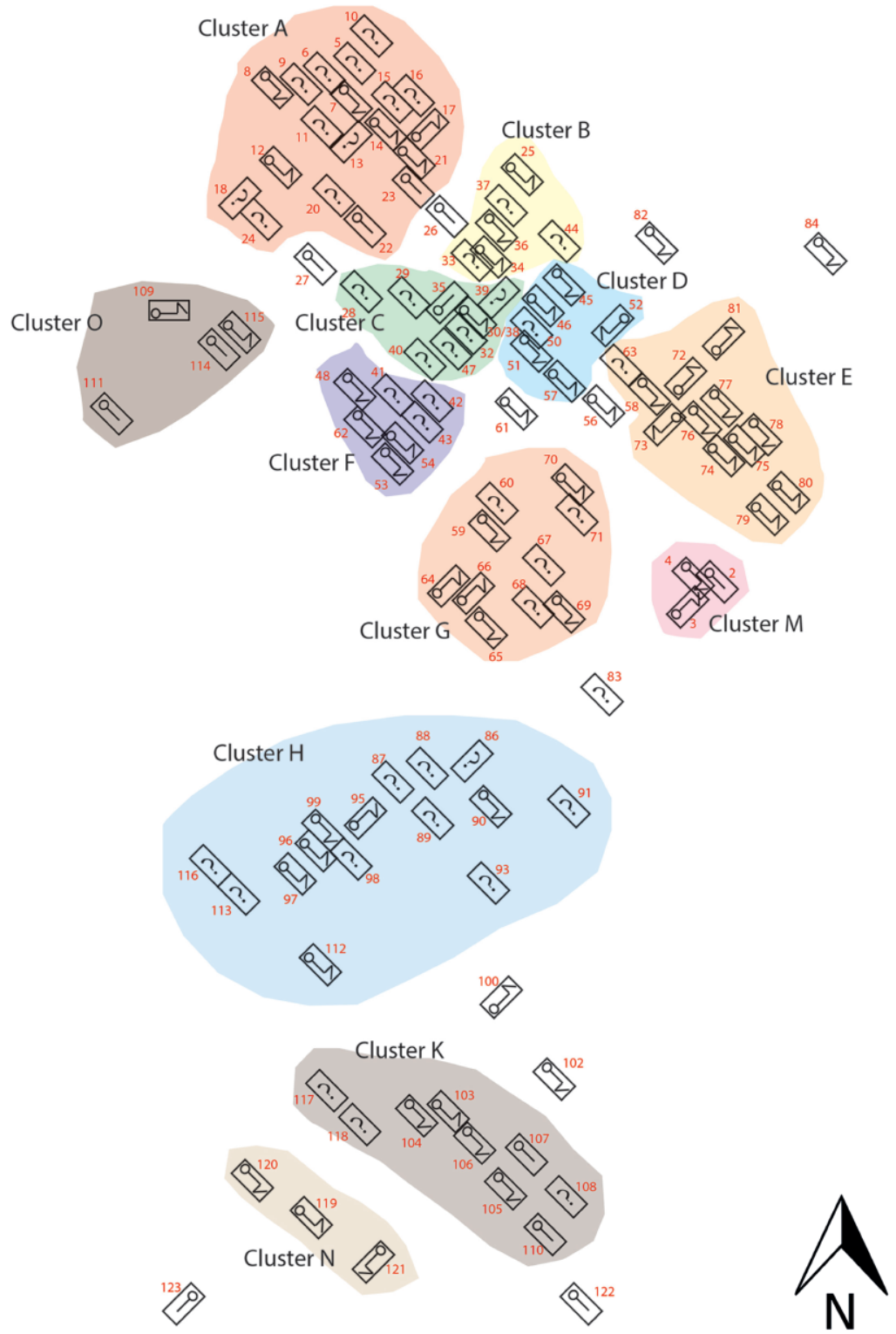

(schematic representation, not to scale)

Figure 4. Ripacandida grave clusters (image: C. Heitz). 
loom weights and spindle whorls are restricted to individuals placed on their left side. Without skeletal remains it is impossible to determine what this binarisation means, especially since particularly richly equipped individuals with loom weights were also placed on their right side and thus transgress the usual pattern. It should be noted, however, that in osteologically determined burials in other south Italian indigenous communities, weapons are strongly associated with males and textile tools with females and are only rarely deposited together (Vida Navarro 1992: 76-77; Gleba 2008: 173; Quercia and Foxhall 2014: 66-67).

Textile traces were found in eight burials in association with bronze and iron personal ornaments such as fibulae and brooches and, in one case, a spearhead. The largest number of textile remains at Ripacandida was associated with richly equipped Tomb 38 (phase 1, cluster C), dated to the very late seventh or early sixth century BC (Setari 1999; Heitz 2018). It was one of the earliest interments in the cemetery, all of which became the nuclei of the later tomb clusters (Heitz 2015; 2018). The pottery in Tomb 38 , primarily of local production, represents a small but full set of the ceramic shapes that form the core of indigenous grave goods across the cemetery: a large olla (storage vessel), an attingitoio (small ladling vessel) and a jug. This set is accompanied by a drinking cup in the same coarse (local) ware as the olla and the attingitoio, whereas the jug is part of a contemporary ceramic tradition developed farther west, the so-called Ruvo-Satriano class (Yntema 1990; Herring 1998; Russo and Di Giuseppe 2008). The personal adornment set is quite elaborate: numerous iron and bronze fibulae, among them amber-clad bow fibulae as well as bronze spectacle brooches. The fibulae on which the textile remains were preserved were most probably located in the area of the right hip. Further goods included a bronze ring, a pyramidal amber pendant and silver spirals known as fermatrecce ('braid-holders', i.e. hair ornaments). This rich assemblage might be taken as a sign that the deceased was a prominent member of the local community.

Very similar was the assemblage of Tomb 54 (phase 2, cluster F). This included a pottery set of local and Ofanto-Subgeometric production (Yntema 1990), numerous fibulae and silver fermatrecce. The iron fibula preserving the textile remains was located on the chest of the corpse.

Tomb 20 (phase 2, cluster A) was rather poorly preserved. The ceramic goods are to be identified as pieces of Ruvo-Satriano ware. The interment was accompanied by several iron and bronze fibulae, among which a single spectacle brooch preserved fabric remains, as well as a spearhead and a large, curved knife.

Tombs 45bis and 45 (phase 2, cluster D) shared the same burial pit. The remains of 45bis are situated directly below Tomb 45 and represent the jewellery deposited with an earlier interment reburied in a small pit below the later corpse. This practice is attested elsewhere in the area (Giorgi et al. 1988: 42; Laimer and Larcher 2006: 40). The individual in Tomb 45 was equipped with a spearhead. Apart from at least three bronze fibulae, remains of iron fibulae were recovered. One of them, a fibula with double-arched bow, preserves textile remains.

Tomb 112 (phase 2, cluster $\mathrm{H}$ ) contained an individual placed on its left side. Traces of textiles were found on one of the bronze spectacle brooches located on the chest, together with at least two other fibulae. The corpse was accompanied by a basic and mixed pottery set.

While the aforementioned graves were of sixth century $\mathrm{BC}$ date, other burials belong to the fifth century BC. Tomb 21 (phase 3, cluster A) contained an individual buried on the left side. It was accompanied by a couple of fibulae, located in the chest area, one of which preserved textile traces. The many pieces of the large ceramic assemblage were now produced and decorated according to the new style that appears to have been used both in colonial and indigenous workshops of south Italy, the socalled banded ware. 
Tomb 53 (phase 3, cluster F) contained the remains of an individual placed on its right side. The relatively rich assemblage of ceramic goods is dominated by banded ware and Greek or Greek-inspired pottery. However, traditional shapes like the olla, jugs and attingitoi are also present, although now decorated in the bandedware manner. Greek shapes (often as bandedware examples) are present, including the krater (mixing vessel), amphora and oinochoe (wine jug). Vessels directly imported from the Greek mainland cannot be identified securely. The corpse was also accompanied by iron objects: at least one simple fibula, a long straight knife and two spears. Only the socket of one of the latter survived; it preserves abundant textile remains.

The range of objects clearly identifiable as textile tools in the graves of Ripacandida is limited and their total number is low: only four complete spindle whorls and eight loom weights (four of which are complete) were recovered. Judging from the size of the bodies as documented by the excavation photographs, the spindle whorls occur in the graves of a sub-adult (Tomb 121) as well as of adult individuals (Tombs 9, 107). They are associated with both comparatively rich (Tomb 9) as well as rather poorly equipped interments (Tombs 71, 109, 121) spread across different grave clusters. Loom weights seem to have been restricted to adult individuals, occurring in both rich and poorly equipped tombs. The rich assemblage of Tomb 36 included three loom weights, while the rest of the tools were placed in the interments associated with modest grave goods, but all of presumably adult age (contra the findings of Osteria dell'Osa: Bietti Sestieri 1992; Robb 1997: 51).

Apart from these clearly identifiable objects, other items probably connected with textile production have been found: a relatively certain example is the needle in Tomb 36. A knife from the same tomb with a short $(9 \mathrm{~cm})$ blade, different from the large ones found in other graves, may also have been used in one of the stages of textile production (Gleba 2008: 158-59). More tentatively associated with textile production activities are two needle-like objects (Tomb 46 , one of iron, one of bronze) that may have been used as fittings for the base ends of distaffs (Heitz 2016: fig. 15; see type B5 in Gleba 2011: 27-30 and similar gold fittings from the sanctuary at San Chirico Nuovo, località Pila, in Russo 2006: 139-41, fig. 138). It is worth noting that all of these items are rooted in the indigenous tradition.

\section{Textiles at Ripacandida: Structural Analysis}

Like the vast majority of protohistoric archaeological textiles recovered in Italy (Gleba 2008; 2017a; 2017b), the fragments excavated at Ripacandida survive due to mineralisation from being in contact with metal grave goods (Figure 5). Mineralised textiles are formations in which metal corrosion products form casts of or around fibres, retaining their external morphology and size almost unaltered either as positive or negative casts (Chen et al. 1998). Even when minute, they can provide a considerable amount of information about ancient textiles, including technical parameters such as thread twist and diameter, weave and thread count per $\mathrm{cm}$ (indicative of textile quality). Using more advanced methods such as scanning electron microscopy it is even possible to identify the nature of fibre. If a number of textile traces are present in a burial, their type, distribution and position, and the direction of the weave in each fragment, when recorded, can help to reconstruct the function of the textile (whether used as garment, wrapping, etc.).

At Ripacandida, remains of 13 different textile weaves were identified on 10 objects or object groups from eight burials (Table 1). Although some of the objects are bronze (e.g. spectacle brooches), in all cases the mineralisation has occurred due to the presence of iron (such as iron pins attached to the bronze brooches). As a consequence, all of the fibre casts are negative. The details of preservation vary and in some cases are obscured by conservation treatment. 
Gleba et al.

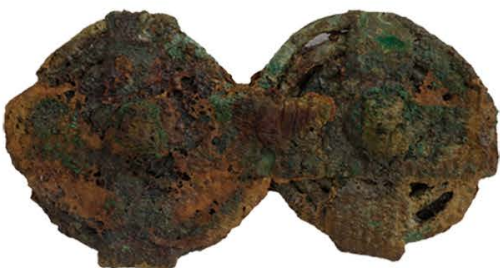

Tomb 20/4 (118311)

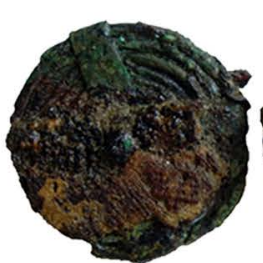

Tomb 45bis (118600)

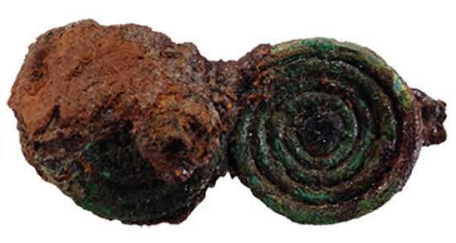

Tomb 112/10

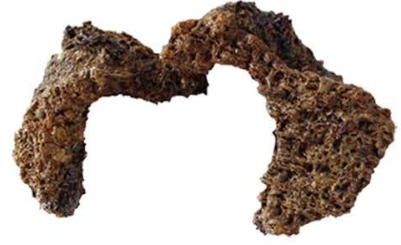

Tomb 45/4

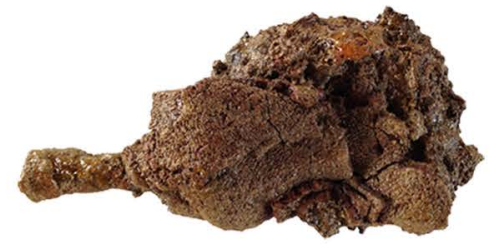

Tomb 21/b (118330)

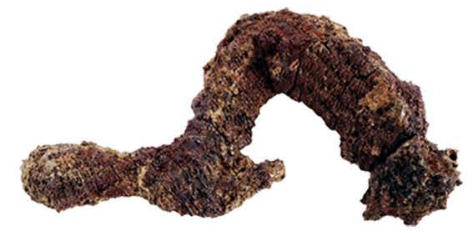

Tomb 54/5 (118766)

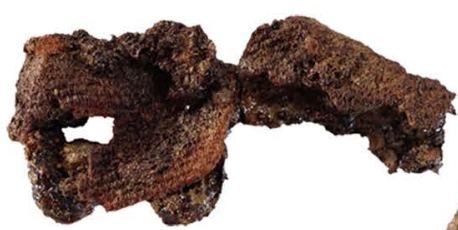

Tomb 38 (118531)

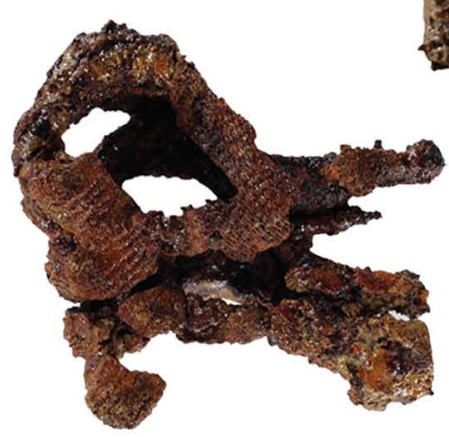

Tomb 38 (118524)

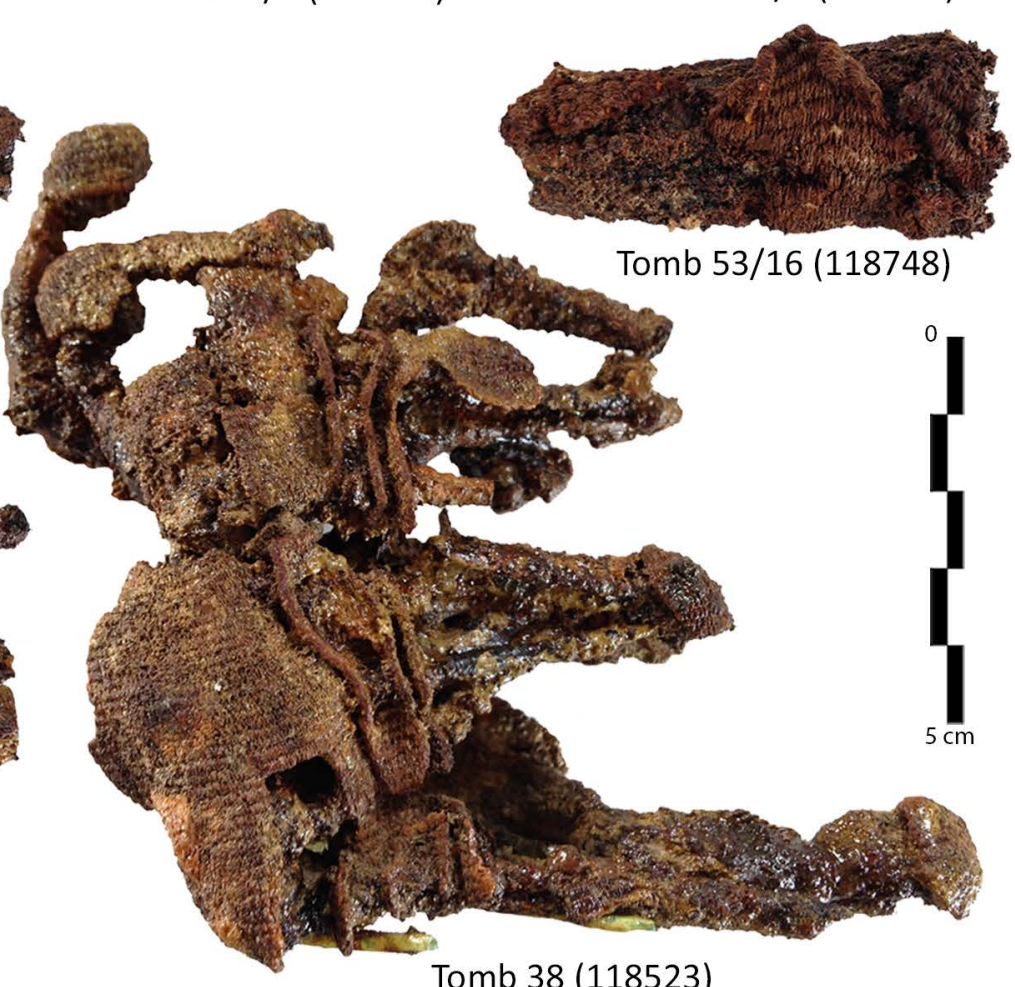

Figure 5. Finds from Ripacandida tombs with mineralised textile traces (images: M. Gleba, F. Meo). 
Table 1. Textile finds at Ripacandida: structural parameters.

\begin{tabular}{|c|c|c|c|c|c|c|c|}
\hline Burial: Object & Inv. No. & $\begin{array}{l}\text { Date } \\
B C\end{array}$ & Position & Weave & $\begin{array}{l}\text { Thread } \\
\text { count per } \\
\text { cm in } \\
\text { warp/weft }\end{array}$ & $\begin{array}{l}\text { Thread diameter } \\
\text { in warp/weft } \\
(\mathrm{mm})\end{array}$ & $\begin{array}{l}\text { Thread twist in } \\
\text { warp/weft }\end{array}$ \\
\hline $\begin{array}{l}\text { Tomb 38: small iron } \\
\text { fibula with double bow }\end{array}$ & $\begin{array}{l}118531 \\
(38 / o)\end{array}$ & $\begin{array}{l}600- \\
550\end{array}$ & right hip & $\begin{array}{l}\text { weft-faced } \\
\text { tabby }\end{array}$ & $10 / 60$ & $0.5 / 0.2-0.3$ & hard z / light z \\
\hline \multirow{2}{*}{$\begin{array}{l}\text { Tomb 38: block of } \\
\text { at least } 7 \text { iron and } 2 \\
\text { bronze fibulae }\end{array}$} & \multirow[t]{2}{*}{$\begin{array}{l}118523 \\
(38 / \mathrm{h})\end{array}$} & \multirow[t]{2}{*}{$\begin{array}{l}600- \\
550\end{array}$} & \multirow[t]{2}{*}{ right hip } & $\begin{array}{c}\text { weft-faced } \\
\text { tabby }\end{array}$ & $9 / 80$ & $0.4-0.5 / 0.2-0.3$ & hard z / light z \\
\hline & & & & tablet weave & 20 tablets & $0.3 / ?$ & hard z / ? \\
\hline \multirow[t]{2}{*}{$\begin{array}{l}\text { Tomb 38: block of } 3 \\
\text { small iron fibulae }\end{array}$} & \multirow[t]{2}{*}{$\begin{array}{l}118524 \\
(38 / b)\end{array}$} & \multirow[t]{2}{*}{$\begin{array}{l}600- \\
550\end{array}$} & \multirow[t]{2}{*}{ right hip } & $\begin{array}{l}\text { weft-faced } \\
\text { tabby }\end{array}$ & $10 / 60$ & $0.4-0.5 / 0.3-0.5$ & hard z / light z \\
\hline & & & & tablet weave & 20 tablets & $0.3 / ?$ & hard z / ? \\
\hline $\begin{array}{l}\text { Tomb 45bis: bronze } \\
\text { spectacle brooch }\end{array}$ & $\begin{array}{l}118600 \\
(45 \mathrm{bis} / \mathrm{f})\end{array}$ & $\begin{array}{l}600- \\
550\end{array}$ & $?$ & $\begin{array}{c}\text { weft-faced } \\
\text { tabby }\end{array}$ & $10 / 60$ & $0.3-0.4 / 0.2-0.3$ & hard z / light z \\
\hline $\begin{array}{l}\text { Tomb 20: bronze spec- } \\
\text { tacle brooch }\end{array}$ & $\begin{array}{l}118311 \\
(20 / 4)\end{array}$ & $\begin{array}{l}550- \\
500\end{array}$ & $?$ & $\begin{array}{c}\text { weft-faced } \\
\text { tabby }\end{array}$ & $8-10 / 40$ & $0.5 / 0.3-0.4$ & hard z / light z \\
\hline $\begin{array}{l}\text { Tomb 45: small iron } \\
\text { fibula with double bow }\end{array}$ & $\begin{array}{l}118591 \\
(45 / 4 c)\end{array}$ & $\begin{array}{l}550- \\
500\end{array}$ & $?$ & tabby? & $4 / 6$ & $1 / 1.5-2$ & $\mathrm{z} ? / \mathrm{z}$ ? \\
\hline $\begin{array}{l}\text { Tomb 54: large iron } \\
\text { fibula with bone-coated } \\
\text { bow }\end{array}$ & $\begin{array}{l}118766 \\
(54 / 5)\end{array}$ & $\begin{array}{l}550- \\
500\end{array}$ & chest & $\begin{array}{l}\text { weft-faced } \\
\text { tabby }\end{array}$ & $6 / 40$ & $0.5 / 0.3-0.4$ & hard $z$ / light $z-i$ \\
\hline \multirow{2}{*}{$\begin{array}{l}\text { Tomb 112: small } \\
\text { bronze spectacle brooch }\end{array}$} & \multirow[t]{2}{*}{$(112 / 10)$} & \multirow{2}{*}{$\begin{array}{l}550- \\
500\end{array}$} & \multirow{2}{*}{ chest } & twill? & & $0.3-0.4 / 0.4-0.5$ & hard $\mathrm{z} /$ medium $\mathrm{z}$ ? \\
\hline & & & & tabby & $20 / 20$ & $0.4 / 0.4$ & $\mathrm{z} / \mathrm{z}$ \\
\hline $\begin{array}{l}\text { Tomb 21: small iron } \\
\text { fibula }\end{array}$ & $\begin{array}{l}118330 \\
(21 / b)\end{array}$ & $\begin{array}{l}500- \\
450\end{array}$ & chest & $\begin{array}{c}\text { weft-faced } \\
\text { tabby }\end{array}$ & $10 / 40$ & $? / ?$ & $? / \mathrm{i}$ \\
\hline $\begin{array}{l}\text { Tomb 53: iron spear- } \\
\text { head }\end{array}$ & $\begin{array}{l}118748 \\
(53 / 16)\end{array}$ & $\begin{array}{l}500- \\
450\end{array}$ & $\begin{array}{l}\text { at } \\
\text { shoulder }\end{array}$ & $\begin{array}{c}\text { weft-faced } \\
\text { tabby }\end{array}$ & $4 / 40-45$ & $0.9-1.1 / 0.3-0.5$ & hard z / light z-i \\
\hline
\end{tabular}

The vast majority of the weaves at Ripacandida are loom-woven in tabby. A tabby or plain weave is the simplest textile structure attainable with two systems on a loom, with vertical warp and horizontal weft threads alternating one over one in each direction. Balanced tabbies have approximately the same number of threads in warp and weft per unit of length (usually expressed in threads per $\mathrm{cm}$ ). Weft-faced tabbies have many more weft threads than warp, and they are so tightly packed that the warp becomes invisible, making it difficult to obtain information regarding the warp-thread structure. One of the textiles found at Ripacandida is a fine balanced tabby (Tomb 112/10); another is probably a coarse, slightly unbalanced tabby (Tomb 45/4c); eight others are weft-faced tabbies (Figure 6).

One possible twill may be present on a spectacle brooch (Tomb 112/10), although the preservation is extremely poor (Figure 7). In a twill, the horizontal weft threads pass over and under vertical warps in a regular staggered pattern, each row being stepped to one side of the row above, creating a diagonal effect.

Finally, two object groups, both from Tomb 38 , preserve traces of tablet weaving (Figure 8). Tablet weaving involves passing threads through holes in the corners of (usually) square tablets which, when rotated forward or back, act as a 


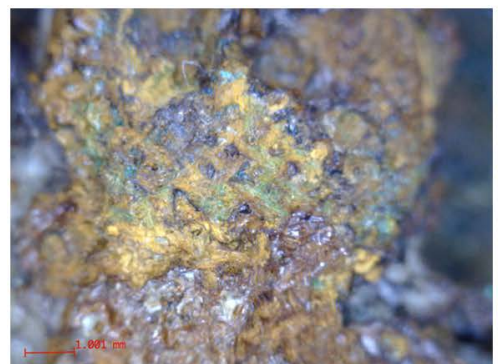

Tomb 112/10

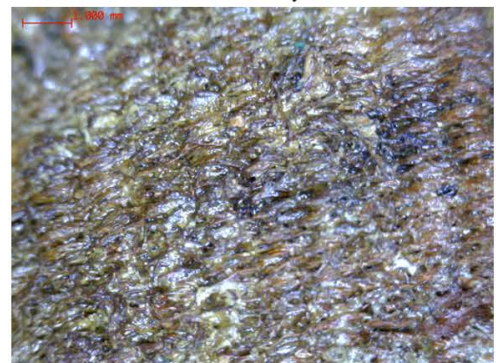

Tomb 38/h (118523)

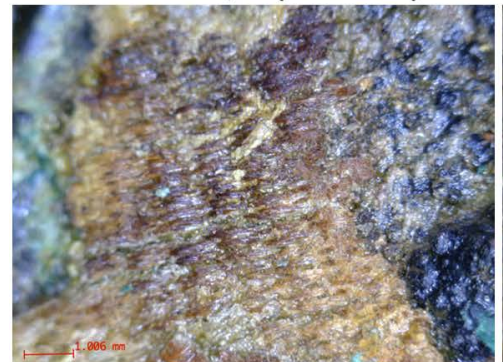

Tomb 45bis (118600)

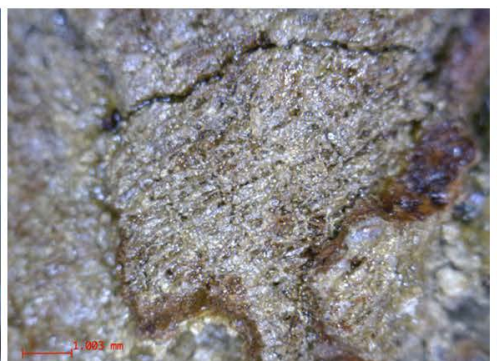

Tomb 21/b (118330)

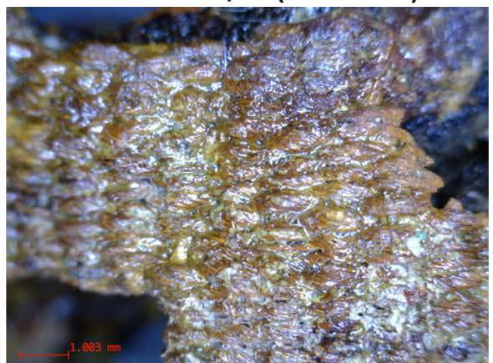

Tomb 38/b (118524)

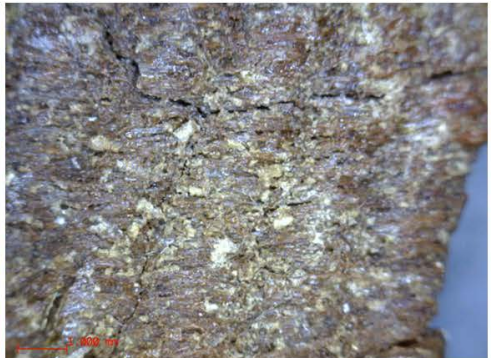

Tomb 54/5 (118766)

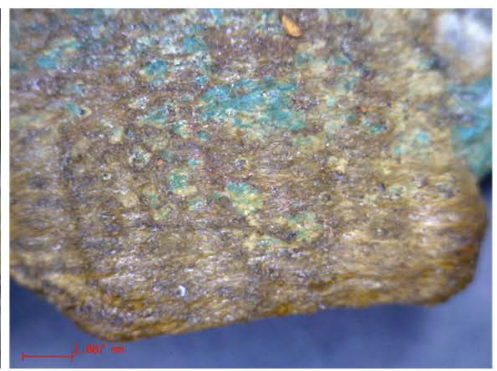

Tomb 20/4 (118311)

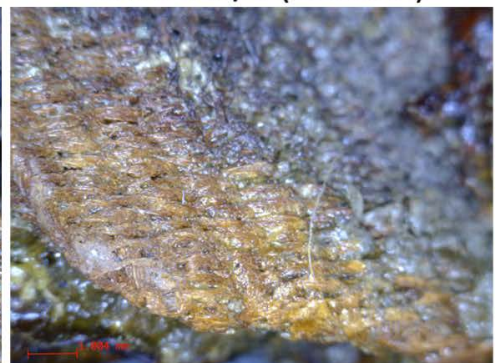

Tomb 38/o (118531)

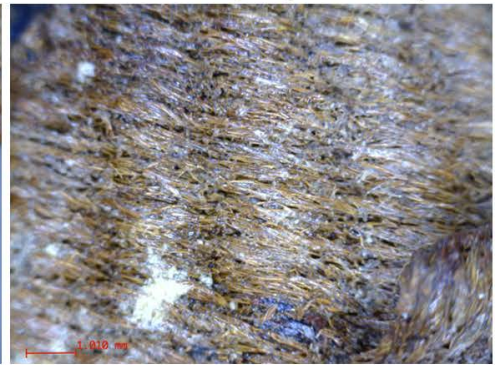

Tomb 53/16 (118748)

Figure 6. Micrographs of tabby (top left) and weft-faced tabby weaves from Ripacandida (images: M. Gleba).
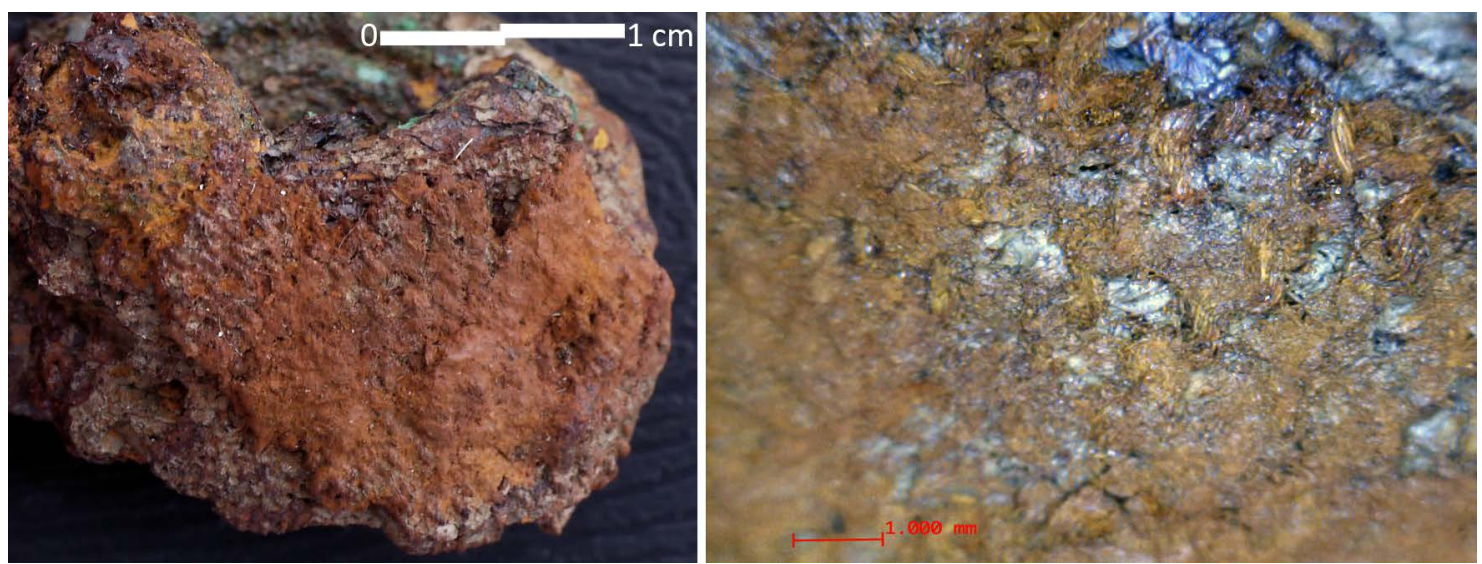

Figure 7. A possible twill on a spectacle brooch from Tomb 112/10 (images: left-H. Landenius Enegren; right-M. Gleba). 

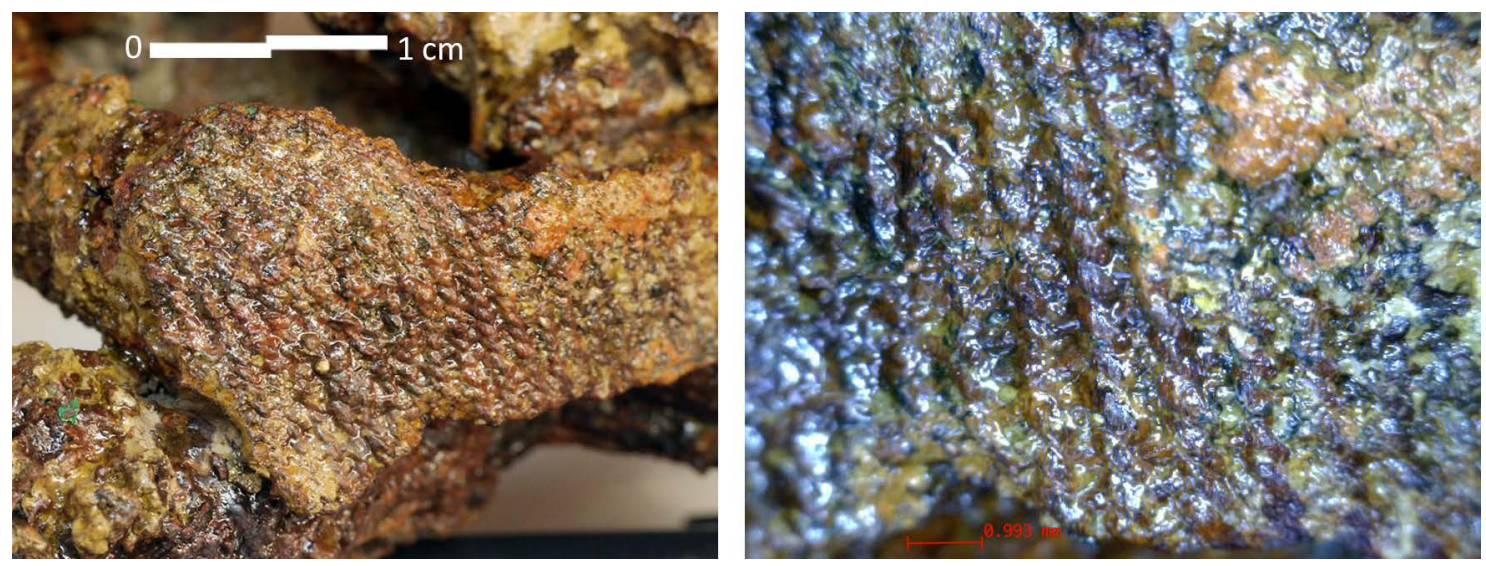

Figure 8. Tablet-woven border on a fibula cluster from Tomb 38/b (118524) (images: left-H. Landenius Enegren; right-M. Gleba).

small loom (Collingwood 1996). By rotating tablets in different combinations, it is possible to achieve patterns. This method is suitable for weaving narrow bands, such as belts, heading bands for the warp of a warp-weighted loom, or decorative borders for the base textile. Such tablet-woven borders are technically complex, extremely labour-intensive, and time consuming. The two tablet weaves at Ripacandida appear to be simple, without variation in tablet rotation direction, but preserved to the width of at least 16 and 24 tablets respectively. While in one case it is not clear if the tablet weave is attached to a ground weave, in the other fragment it appears to be a border attached to a weft-faced tabby. Given their technical similarities and the fact that both come from the same grave and were found in close proximity, they probably belong to the same textile with a tablet-woven border.

All of the textiles at Ripacandida were woven using $\mathrm{z}$-twisted (the conventional way of indicating clockwise spin direction) threads, which is typical for the Italian peninsula during the proto-historic period (Gleba 2017a; 2017b). The weft-faced tabbies, furthermore, have other characteristics in common: they are all woven with hard z-twisted warp and a weft that has a weak $\mathrm{z}$ twist, or else they do not have any discernible twist at all (Figure 9). Such a configura- tion allows the tightly twisted warp to withstand the frequent abrasion of changing sheds during weaving and the less tightly twisted weft threads to be packed more tightly between the warps whilst retaining the softness of the fabric. In contrast, twills and tablet weaves usually have tightly twisted yarn in both systems, which is necessary for the pattern and structural stability of the weave. In weft-faced tabbies, the warp diameter slightly exceeds the weft thickness. The thread count does not exceed 10 in warp whereas it is over 40 in weft, in some cases reaching 60 and even 80 threads per $\mathrm{cm}$. Except in one case where a simple selvedge is preserved (Tomb 53), none of the textiles preserve edges. Based on the analysis of similar finds across Italy and elsewhere (Gleba 2017a; 2017b), weft-faced tabbies, twills and tablet weaves were likely made of sheep wool.

The nature of the textile weaves (weft-faced tabbies, a possible twill and tablet weave-all of which are usually used for garments), their association with a variety of mostly personal metal ornaments, and the position of textile remains in the tombs (where known), suggest that the dead were probably not buried in shrouds (which tend to be in a balanced tabby weave), but dressed (or at least wrapped) in clothes. This is particularly indicated by the differing number and position of the fibulae and brooches, which 


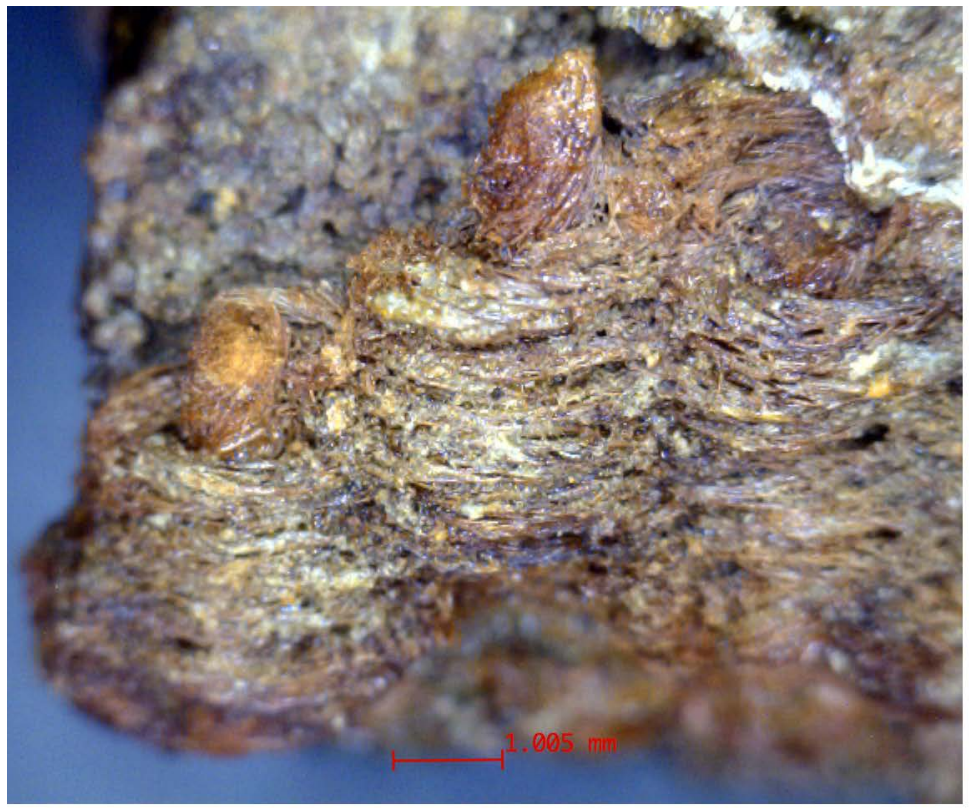

Tomb 53/16

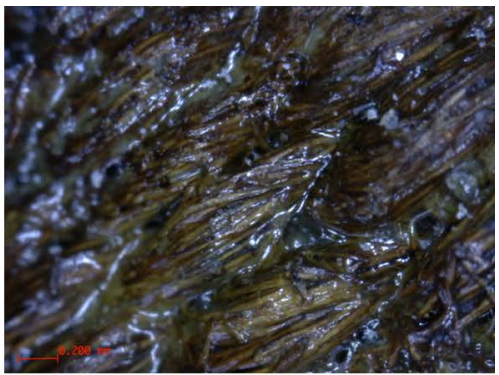

Tomb 38 (118524)

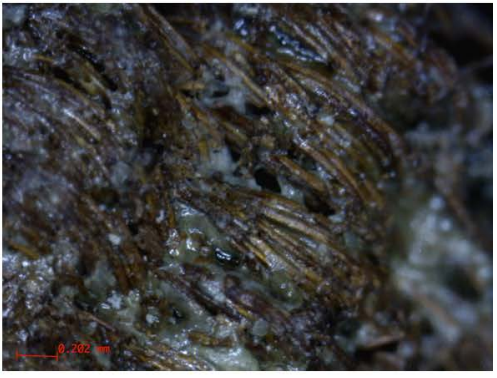

Tomb 38 (118531)

Figure 9. Micrographs of loosely twisted weft threads in weft-faced tabbies from Ripacandida; note two tightly twisted warp threads in the left image visible where the weft broke off (images: M. Gleba).

were attached to the garments and facilitated the preservation of their traces through mineralisation. In Tomb 38, multiple fibulae are preserved together, piercing several layers of the same rather fine textile (Figure 5). In Tomb 112, two different weaves were identified, suggesting two different garments made in balanced tabby and twill respectively, layered one on top of the other.

\section{Textile Tools at Ripacandida: Functional Analysis}

The textile tools found at Ripacandida include four spindle whorls and eight loom weights. Despite the limited number of textile tools, a situation not unusual in a funerary context (Gleba 2008: 171, 174), careful analysis sheds light on their productive possibilities in the absence of data from domestic contexts at Ripacandida. The tools were analysed following the method developed at the Centre for Textile Research (CTR) in Copenhagen, which allows estimating textile qualities on the basis of loom weight thickness and weight values based on experimental archaeology, in which reconstructions of textile tools found in archaeological contexts were tested by craftspeople who specialised in textiles (Andersson Strand 2013; 2014; Andersson Strand et al. 2015). The experimental testing has demonstrated that textile tool parameters such as the weight and diameter of spindle whorls and the weight and thickness of loom weights correlate with variations in the quality of the textiles themselves, providing insight into thread quality and type of cloth and thus pointing to the type of textiles manufactured at any given archaeological site (Olofsson 2015).

\section{Spindle Whorls}

Spindle whorls are small, symmetrical objects of different shapes and materials with a central perforation intended to be inserted onto a spindle - a thin rod made of wood, bone or metal-in order to facilitate the spinning of 


\section{$5 \mathrm{~cm}$}
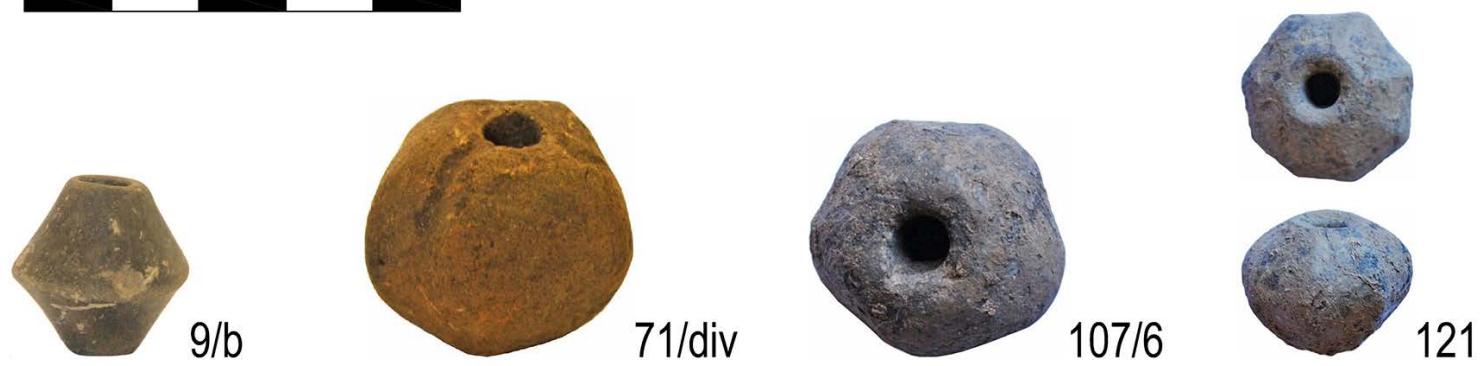

Figure 10. Spindle whorls from Ripacandida tombs (image: C. Heitz / M. Laimer).

fibres into thread. The placing of the whorl on the spindle is culturally determined, and thus we speak of high-whorl and low-whorl cultures (Barber 1991: 53). In Italy, as in most of Europe, the low-whorl spindle was in use until the Roman period (Gleba 2008: 100-103). The most important parameters of a spindle whorl—its weight and height/diameter ratioinfluence the thread quality produced, which is also dependent on the type of fibre being spun.

Four ceramic spindle whorls were found at Ripacandida (Figure 10): one biconical (Tomb $9 / \mathrm{b}$ ) and three spherical faceted (tombs $71 / \mathrm{div}$, $107 / 6,121 / 7$ ). Items from $9 / \mathrm{b}$ and $71 /$ div do not have exact find spots, but 107/6 was found in proximity of the head and 121/7 in the hip area.

The four spindle whorls from Ripacandida range in weight from 8 to $24 \mathrm{~g}$ (Table 2). Light whorls such as the item weighing $8 \mathrm{~g}$ would have been suitable for spinning very fine wool. However, experimental testing of spindle whorl replicas weighing $8 \mathrm{~g}$ and $19 \mathrm{~g}$ using wool fibre demonstrated that the difference in the resulting thread diameter is marginal, both being fine thread qualities (Möller-Wiering 2015:
104). The data thus suggest that the whorls at Ripacandida were used for the manufacture of fine-quality thread. The variation may have been in the tightness of the twist, rather than the diameter.

\section{Loom Weights}

In a warp-weighted loom, which was the prevalent type in pre-Roman Europe (Barber 1991), the function of loom weights is to keep the sets of warp threads taut, thus facilitating the insertion of the horizontal weft threads. Warp threads of different material, diameter and strength need different tension for optimal weaving to take place. Loom weights of different weight and thickness are suitable for different types of weaves.

There were eight loom weights among the Ripacandida finds (Figure 11). They are of truncated pyramidal (frustum) shape, typical for south Italy (Gleba 2008: 131; Quercia and Foxhall 2014: 65; Landenius Enegren 2015: 13141; Meo 2015: 66-68). None are decorated. The find position in the grave is only recorded in the case of Tomb 66, where the loom weight was

Table 2. Types, weight and diameter of spindle whorls at Ripacandida.

\begin{tabular}{llcc}
\hline Inv. Number & Type & Weight $(\mathrm{g})$ & Diameter $(\mathrm{mm})$ \\
\hline $9 / 5$ & biconical & 9 & 23.7 \\
$71 /$ div & spherical (5 facets) & 24 & 31.6 \\
$107 / 6$ & spherical (5 facets) & 15 & 28.2 \\
$121 / 7$ & spherical (7 facets) & 8 & 22.1 \\
\hline
\end{tabular}

() Equinox Publishing Ltd., 2018 


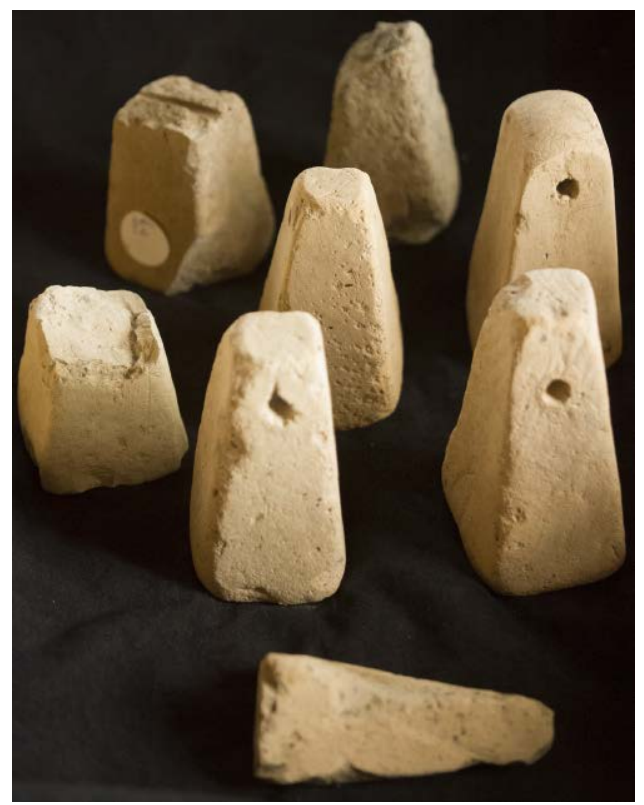

Figure 11. Loom weights from Ripacandida tombs. The thickness of the loom weights ranges between $43 \mathrm{~mm}$ and 47 mm (image: H. Landenius Enegren).

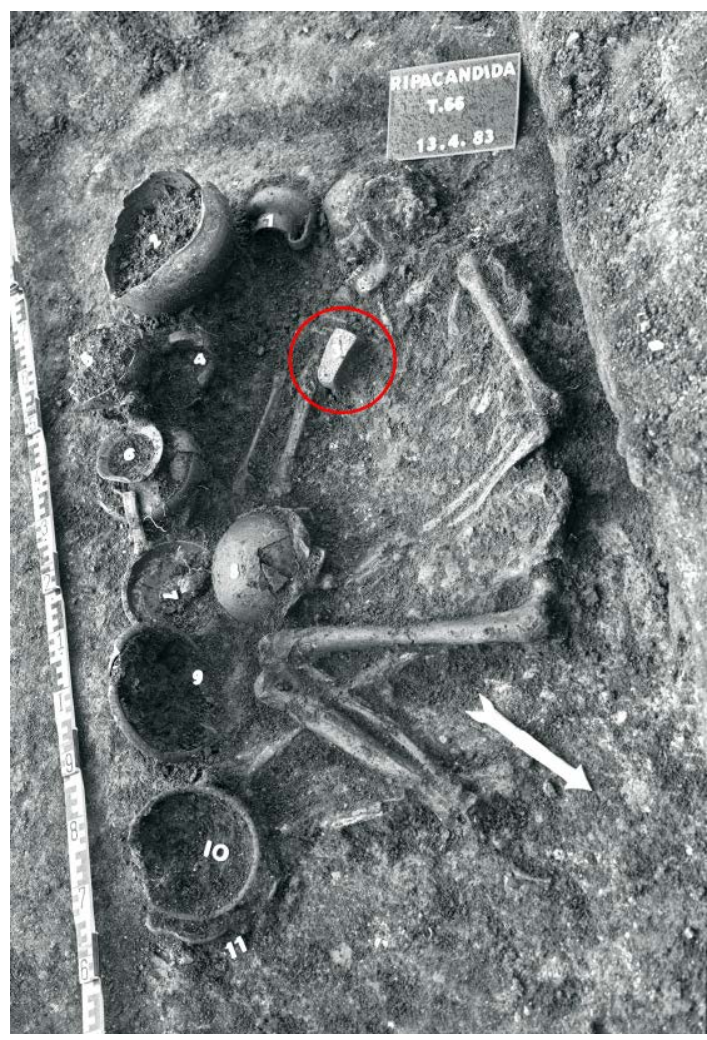

Figure 12. Ripacandida Tomb 66 with the location of the loom weight in situ circled (image: Soprintendenza per i Beni Archeologici della Basilicata / C. Heitz). 
placed directly on the chest, almost as if worn around the neck (Figure 12).

The estimated weights of the four fragmentary loom weights correlate with those of the four complete objects, ranging between 166 and $213 \mathrm{~g}$. Although this is a small sample, the results of the calculations of potential loom set-ups, based on the CTR method (Andersson Strand et al. 2010), demonstrate that the loom weights at Ripacandida were well suited to a weave in which the warp threads would require a tension of 10-20 g. A sample calculation of one of the loom weights (RC04 118928.66/3) is provided in Table 3 . The relatively low warp thread count of 3-4 and 7-8 threads per $\mathrm{cm}$ would indicate either a very open balanced tabby, or a weft-faced fabric.

\section{Textile Cultures of South Italy}

Comparing the results of the analyses of the textiles and textile tools at Ripacandida allows us to make several important observations regarding the production and consumption of cloth at the site, despite the absence of settlement data. First, the notion that the textiles produced with the loom weights recovered at the site were likely to be weft-faced is mirrored by the predominance of weft-faced tabbies in the textile assemblage. Moreover, the warp thread count per $\mathrm{cm}$ of the mineralised weft-faced tabbies
(4-10 threads per $\mathrm{cm}$ ) correlates with those in the potential loom set-ups (7-9 threads per $\mathrm{cm}$ with a $10 \mathrm{~g}$ tension as optimal, but with a wider range of 3-18 threads per $\mathrm{cm}$ being possible at thread tensions between 5 and $20 \mathrm{~g}$, thus fully concordant with the textile qualities represented at Ripacandida). This suggests that these implements may have been used in the manufacture of the cloth and subsequently placed with their owners in the graves.

Thanks to the recent studies of tools at other Archaic sites of south Italy, we are in a position to contextualise the Ripacandida results in a wider geographical and cultural area. Analysis of tools from two indigenous Messapic Archaic settlements in Puglia-Cavallino and San Vito dei Normanni-indicates production of textiles very similar to those of Ripacandida (Landenius Enegren 2015: 133-36). The loom weights at Cavallino would have been optimal for producing fabrics using threads requiring a tension of 10-20 $\mathrm{g}$ and with a warp thread count range of 4-12 threads per $\mathrm{cm}$. The loom weights at San Vito dei Normanni give a similar outcome: 10-20 g thread tension and 5-10 warp threads per $\mathrm{cm}$. At the Lucanian indigenous site of Torre di Satriano in Basilicata, the first, apsidal building from the end of the seventh century BC until 570-560 BC preserved loom weights of two types. These are optimal for a setup using threads with a tension of $30-70 \mathrm{~g}$ per thread

Table 3. Calculations of the number of warp threads using a set of Ripacandida loom weight nr. RC04 118928 based on the CwTR method.

\begin{tabular}{|c|c|c|c|c|}
\hline \multicolumn{5}{|c|}{ Loom weight nr.RC04 118928 (66/3): weight 181g, thickness $47 \mathrm{~mm}$} \\
\hline & $A$ & $B$ & $C$ & $D$ \\
\hline Warp threads requiring & $5 \mathrm{~g}$ warp tension & $10 \mathrm{~g}$ warp tension & $20 \mathrm{~g}$ warp tension & $30 \mathrm{~g}$ warp tension \\
\hline $\begin{array}{l}\text { Number of warp threads } \\
\text { per LW }\end{array}$ & 36 & 18 & 9 & 6 \\
\hline $\begin{array}{l}\text { Number of warp threads per } \\
2 \text { LWs (one in front and one } \\
\text { in back) }\end{array}$ & 72 & 36 & 18 & 12 \\
\hline Warp threads per $\mathrm{cm}$ & 15 & $7-8$ & $3-4$ & $2-3$ \\
\hline Evaluation of suitability & Possible & Choice & Choice & Unlikely \\
\hline
\end{tabular}


in the case of the heavier examples, resulting in a very open tabby fabric, since the number of threads per $\mathrm{cm}$ varies from 3 to 6; or a setup using tension of 5-10 $\mathrm{g}$ for the lighter specimens, resulting in 6-13 warp threads per $\mathrm{cm}$ (Quercia 2017: 251). In contrast, almost 400 loom weights associated with the second, late sixth- to early fifth-century BC building were calculated to require 5-7.5 g tension, resulting in a range of warp count between 9-10 and 13-15 threads per $\mathrm{cm}$, if a twill weave were hypothesised, or between 5 and 7 threads per $\mathrm{cm}$ in a tabby (Quercia 2017: 256).

Similar results are seen in the Archaic Greek settlements of south Italy. Three sets of loom weights have been discovered in an Archaic house at Kaulonia, and all of them would have been optimal for producing fabrics using threads requiring $5-7.5 \mathrm{~g}$ tension, resulting in warp thread count of 4-11 threads per cm (Luberto and Meo 2017). Loom weights at Herakleia, found together with Archaic material and coming both from Taranto and Herakleia, weighed between 50 and $100 \mathrm{~g}$ and would have been optimal for fabrics using threads with 5-7.5 $\mathrm{g}$ tension, resulting in the warp density of 6-9 threads per $\mathrm{cm}$ (Meo 2015: 66-68; 2018).

Although research into textile tools of south Italy is only beginning, these first results suggest that, during the Archaic period, the threads of the Greek poleis needed a slightly lower tension than those of the indigenous settlements. Yet both the indigenous and Greek settlements of south Italy produced fabrics that had a relatively low warp density, usually not exceeding 10-12 threads per $\mathrm{cm}$, and were likely weft-faced. So how does production of weft-faced tabbies in south Italy fit within a wider picture?

The earliest weft-faced tabby identified to date in Italy comes from the eighth-century BC Fondo Artiaco Tomb 104 at Cumae, one of the earliest Greek foundations in Italy, and has numerous technical characteristics indicating that it is an import (Gleba and Vanden Berghe n.d.). Otherwise, weft-faced tabbies are generally not known in Italy before the seventh century вс (Gleba 2017a; 2017b). Numerous examples have been found at Alfedena in the Abruzzo region, an area that was culturally associated with the Adriatic basin during the Iron Age (Nijboer 2011); in a few exceptionally rich Etruscan and Latial burials, which also contained an extraordinary quantity of eastern Mediterranean imports, e.g. at Grotte di Castro (Gleba and Laurito 2015: 338); and in south Italy, dating to after the foundation of Greek settlements. In the Bay of Naples area, weft-faced tabbies have been observed among Archaic-period finds from Cumae (Gleba et al. 2017). In Basilicata, they have been found at Chiaromonte, specifically Tomb 325. Finally, closest to the cultural sphere of Ripacandida, a weft-faced tabby is present on a fibula from Archaic Ascoli Satriano (Tomb 11/13; the authors have seen a photograph kindly provided by Dr Astrid Larcher).

All other pre-seventh-century BC textile finds in south Italy (so far not very numerous) are twills. These include the still unanalysed finds from Torre Galli in Calabria (Pacciarelli 1999: pl. 189.E-I), dated to the tenth to ninth centuries $\mathrm{BC}$; a $2 / 2$ chevron twill of exceptional quality dated to the eighth century BC, found at Incoronata San Teodoro in Basilicata (Gleba 2017b); and a 2/2 twill from Tomb 53 at San Marzano sul Sarno in Campania, dated to the end of the ninth century BC (Gleba 2008: 57, 59, fig. 46). In fact, recent analysis of numerous mineralised textile fragments preserved in burials demonstrates that, during the Iron Age, indigenous Italic populations from Veneto to Basilicata were producing wool textiles woven in twill weave (Gleba 2017a; 2017b). These twills are often spin- or shadow-patterned, i.e. made using alternating groups of threads spun in opposite directions, which would have created a subtle damask-like pattern of checks or stripes. The textiles are usually balanced, having a similar number of threads in warp and weft, which are around 20-30 threads per $\mathrm{cm}$. Last but not least, these twill textiles often have tablet-woven 
borders. Close connections in terms of textile technology can be found with the Eastern Hallstatt Culture (Grömer et al. 2013), indicating that Italy was part of a wider central European textile culture (Gleba 2017b).

In contrast, the vast majority of Greek Iron Age and Archaic textiles are tabbies or weftfaced tabbies (Spantidaki and Moulhérat 2012; Spantidaki 2016; Gleba 2017b). There is no evidence of spin- or shadow-patterning, and the weft threads usually have only weak twist or no discernible twist at all. There is also no direct evidence to date of the use of tablet-woven borders in any of the Greek textiles. Nor do the archaeological textile remains thus far found on Cyprus have such borders; rather, they show balanced tabbies (Landenius Enegren and Vanden Berghe 2016). The Late Bronze Age sites of Enkomi and Kition produced 'fine fabrics that were weft-faced' (Sauvage and Smith 2016: 203). Greek textile culture is much closer to the traditions of the Near East, where balanced tabbies and weft-faced tabbies have also been discovered with, as yet, no direct evidence of twills or tablet weaves (Gleba 2017b). This tabby-based textile culture appears to have spread westwards by the seventh century BC as part of direct or indirect contact with the Greeks, and by the end of the first millennium BC it essentially supplanted the indigenous Italian twill tradition.

Greek weft-faced tabbies are, in many cases, finer in terms of thread diameters and thread counts than any of the fabrics of the same type found in Italy, Ripacandida examples included. Weft diameters in Greek weft-faced tabbies are often less than $0.2-0.1 \mathrm{~mm}$ and the weft count can reach very high numbers-over 80 and, in some cases, over 110 threads per $\mathrm{cm}$ (Gleba 2017b). The only example of this quality found in Italy is a likely import from Cumae (Gleba and Vanden Berghe n.d.). Curiously, calculations based on loom weights carried out at Herakleia and Kaulonia suggest that the threads optimally suited for them would have been ca. $0.1-0.3 \mathrm{~mm}$ in diameter, whereas those used at contemporary indigenous sites would have been thicker, ca. $0.3-0.5 \mathrm{~mm}$ (Landenius Enegren 2015; Meo 2015; Luberto and Meo 2017). Both textiles and tools thus indicate that, even though the textile technique was the same, Greeks both at home and in their western colonies may have produced finer cloths.

The explanation for this difference may have to do with skill level, but could also be the result of differences in the raw materials available to and used by different populations in Italy and Greece. Wool-fibre diameter studies have suggested that, during the first millennium BC, several distinct wool qualities coexisted within Italy and more broadly across Europe, possibly reflecting the use of several distinct sheep types (Gleba 2012). In the meantime, a recent archaeozoological study has demonstrated a distinct and significant change in the size of domestic sheep in southern Italy following Greek colonisation (Gaastra 2014). This change could have resulted either from the translocation of Greek domesticate varieties to the colonies, or from the local development of 'improved' varieties (Gaastra 2014: 495). According to some literary sources, the polis of Sybaris imported Milesian wool to weave fine garments (Timaeus of Tauromenium, F 50 in $F G r H=$ Athenaeus 12.519b). If Greeks 'imported' to south Italy sheep varieties particularly suitable for the production of weft-faced tabbies, it might explain the differences in textile quality between weft-faced tabbies produced at indigenous sites and those woven in the Greek poleis.

The possibility thus remains that not only techniques and fashions but also sheep providing wool of a quality particularly suitable for the production of fine weft-faced tabbies may have arrived in south Italy along with Greek settlers. As with many other aspects of Greek culture, however, the adoption was not wholesale; rather, some aspects of Greek textile culture were adapted to local needs and desires. In this respect, the discovery at Ripacandida of a unique weft-faced tabby with an integral 
tablet-woven border is particularly significant. It combines what we see as a typically 'Greek' weave structure with a typically 'Italic' border and may thus indicate the development of a new, mixed-textile culture which combines two distinct technologies belonging to different traditions.

Borders are well illustrated in Etruscan and Italic representational material (Bonfante 2003; Nieling 2007). Scholars argue that they were not purely decorative but served as indicators of status and rank (Raeder Knudsen 2012; Stauffer 2012). The textiles may have served as indicators of social rank or as 'ceremonial' clothes, with the border functioning as the distinguishing element characterised by technique, pattern and colour. Their importance is emphasised by the fact that the consumers of the textiles found at Ripacandida, whilst adapting the new textile weave from their Greek neighbours, chose to retain the border in the production process.

\section{Textiles and Greek-Indigenous Interaction in South Italy}

How, then, can we interpret textile production and consumption at Ripacandida in light of Greek-indigenous interaction in south Italy? From a technical point of view, most of the textiles at Ripacandida are relatively high-quality weft-faced tabbies likely made of sheep's wool. The results of the analyses of the textile tools found in the burial assemblages correlate with the structural analysis of the fabrics, suggesting that, at some point at least, they could have been used to produce fabrics very similar to those found in tombs. Nevertheless, whilst the predominance of weft-faced tabbies at indigenous Ripacandida indicates a clear connection with the Greek textile tradition, the presence of a characteristic Italic tablet-woven border on one of the textiles reflects a mixed textile culture. How did it evolve?

The material culture in the graves of Ripacandida (specifically pottery) testifies not only to the firm-rootedness of the community in the Italic tradition, but also to the wide range of its connections, from the lowlands of northeast Apulia (Daunia), up into modern Campania in the west (Ruvo-Satriano area) and to the Greek settlements in the south/southeast (imports and banded wares). One possible explanation for this wide range of contacts is that the community was partly mobile (for full range of arguments see Heitz 2017). The remarkable local askoi (squat pouring vessels) with bull's-head protomes and ram-shaped bronze pendants suggest a high significance and prestige attached to livestock ownership and the practice of stockbreeding (Heitz 2015; 2016; 2018). Mobile pastoralism (transhumance) is historically well attested in this area from the second century $\mathrm{BC}$ until the middle of the twentieth century AD (e.g. Garnsey 1988; Santillo Frizell 1996; Petrocelli 1999), to such an extent that Braudel (1996 [1939].1: 85-102) classified it as an important element of the longue durée.

Ripacandida might have served as a stopover point on the seasonal routes between the upland summer and lowland winter pastures in the Apulian coastal region, mirroring exactly the course of the routes that the so-called statonica transhumance took until recently (Sprengel 1971: 135-40). Unlike nomadism, in mobile pastoralism the phases of movement only cover some days or weeks, while the stationary phases last weeks or even months (see e.g. Carrier 1932: 8; Hütteroth 1959: 38; Carrer 2015: 10). Often inextricably connected to sedentary populations, ethnographically documented mobile pastoralist economies are highly dependent on the existence and potential of markets, where a large proportion of raw products like milk/cheese and wool would be sold to sedentary communities engaged in their further processing in exchange for finished products and other goods (e.g. Hütteroth 1959; Barth 1961: 8-9; Ferdinand 1969: 136; Petrocelli 1999; Mientjes 2004; 2010).

Such a practice, ethnographically documented in modern mobile pastoralists, may shed more 
light on the indigenous-Greek relationship if we suppose that textile production was indeed a major factor in Greek-indigenous exchange and even co-operation: while the wool was generated by indigenous semi-mobile pastoralists, textile production was largely in the hands of settled Greek (and other indigenous) communities such as Metaponto or Taranto. The latter is well documented as a major textile-producing centre, at least in written sources, since the Archaic period (Meo 2015: 37), and one that exerted strong influence over the surrounding territory, including over the organisation of textile production. Quercia and Foxhall (2014: 69) interpret the standardisation of the later group of loom weights at the indigenous site of Torre di Satriano in shape, size, weight and manufacturing techniques as indicative of the adoption of Greek (Tarantine) weaving traditions.

Indigenous populations may have initially obtained weft-faced tabby textiles from Greek sources, but they soon took up the weaving technique itself. When a new craft technology is adopted, the necessary knowledge and knowhow must be acquired from a different community of practice (Lave and Wenger 1991; Wenger 1998; Wendrich 2012). The indigenous weavers could have learnt the weft-face tabby technique during the prolonged stationary (winter) phase of transhumance when the exchange of the raw materials took place, as the transmission of the necessary knowledge and technical skills would have required more or less extended contact between the apprentice and a skilled practitioner, the amount of time depending on the learner's knowledge and skill (Cutler 2012: 148-49).

The presence of weft-faced tabbies at other indigenous sites, such as the nearby Ascoli Satriano and more distant Chiaromonte, suggests that Ripacandida community was not alone in taking up the new technique, although the reasons behind the adoption of the weft-faced tabby by south-Italian indigenous weavers is more difficult to disentangle. Was it the novelty factor, or part and parcel of new fashion? Did it present new technical possibilities (e.g. creation of tapestries with figural decoration)? Was it desirable for its texture, drapability or appearance, or was there perhaps some other perceived appeal? Whatever the reason, the adoption of weft-faced tabby was not universal and some of the indigenous communities of south Italy continued to produce traditionally Italic twills long after the arrival of a new Greek cloth type. The recent discovery of twill textiles, which preserve complex geometric decorative patterns, in the warrior's Tomb 382 at Ordona (ancient Herdonia), dated to ca. $400 \mathrm{BC}$, demonstrates that at least Daunian elites continued to use twills (Catalli et al. 2018).

Even at Ripacandida the new technique was not adopted wholesale: it was combined with a long-standing tradition of adding tablet-woven borders, as exemplified by the finds from Tomb 38. These borders were clearly indispensable identity indicators among the Italic populations that were not susceptible to the influences of new fashions or techniques.

\section{Conclusions}

Textile culture based on wool twills and tabletwoven borders was well established in south Italy, as elsewhere on the Apennine Peninsula, by the beginning of the Iron Age. During the Archaic period, in certain situations, contact with the weft-faced tabby-based Greek textile culture gave way to the creation of new expressions. The remains found at Ripacandida provide the first example of how textile traditions and their elements (indigenous vs. Greek) met and were indeed combined in south Italy. A (partially) mobile character of the Ripacandida population (Heitz 2017) may have been the key reason for its quick uptake of the new type of weave, likely initially through exchange of ready-made cloth with the Greek newcomers.

For the time being, the textile culture at Ripacandida is unique and, in our opinion, is the direct consequence of prolonged and intimate 
interaction between textile workers from the indigenous communities and settled Archaic Greek communities (however they came into contact with each other), which would have been a conditio sine qua non for the technological exchange to happen between them. Yet the use of tablet-woven borders on a weft-faced tabby underscores preoccupation with the local, Italic, audience, for whom their significance as status markers would have been quite clear. Indigenous-Greek interaction resulted in the creation of this unusual mixed-textile culture, which finds comparison in the production of vessels of indigenous shape and Greek-style decoration or vice versa (Carpenter et al. 2014). We deliberately avoided the use of the term 'hybrid' here, as at this time our evidence is too singular to argue that the Ripacandida textiles are a result of the creation, through interaction and negotiation, of new transcultural forms, ambiguous cultural affiliations and/or meanings (sensu van Dommelen 2005: 118). We can only hope that as more textile finds are analysed from other sites in the region, our understanding of local textile cultures and their interaction will obtain the necessary depth. Ripacandida is the first harbinger of this textile revolution.

\section{Acknowledgements}

Margarita Gleba's research has been funded by the European Research Council under the European Union's Seventh Framework Programme (FP/2007-2013-312603), the project Production and Consumption: Textile Economy and Urbanisation in Mediterranean Europe 1000-500 BCE (PROCON). Christian Heitz's research on the general finds of the necropolis received funding from the Dr.-Walther-Liebehenz-Stiftung, Göttingen. The study of the cemetery was originally suggested by Massimo Osanna, while access to the material was kindly granted by the director of the Soprintendenza per i Beni Archeologici della Basilicata, Antonio De Siena. Many of the thoughts on transhumance presented in this paper originated while generously funded by the Austrian Science Fund FWF (Project no. M 1563-G19). Hedvig Landenius Enegren's research was funded by a FP7 Marie Curie Fellowship Grant PIEF-GA-2011-298974 (DIASPORA), the project West and East: Textile Tool Technologies and Identities in the 1st millennium B.C. South Italy and Cyprus. Francesco Meo carried out this research within the project L'attività tessile nell'Italia meridionale preromana: tecniche, tecnologie, materiali e protagonisti (nr.JPCNYJ5), co-funded by the Fondo di Sviluppo e Coesione 2007-2013-APQ Ricerca Regione Puglia Programma regionale a sostegno della specializzazione intelligente e della sostenibilità sociale ed ambientale-FutureInResearch'. We wish to thank Beatriz Marín Aguilera and Lieve Donnellan for their insightful comments on the drafts of this paper.

\section{About the Authors}

Margarita Gleba is currently ERC Principal Research Associate at the McDonald Institute for Archaeological Research, University of Cambridge, UK. She was previously a research project manager at the Centre for Textile Research, University of Copenhagen, Denmark, and Marie Curie Fellow at University College London, UK. Her research interests include the archaeology of the pre- and protohistoric Mediterranean and Near East. She specialises in textile archaeology, including scientific analytical methods of fibre and textile investigation.

Christian Heitz is currently affiliated with the Institut für Archäologien, University of Innsbruck, Austria, as Senior Assistant Professor. $\mathrm{He}$ has conducted research on Aegean Bronze Age archaeology as well as on Roman Art and Italian Iron Age contexts. He is currently director of the excavations at Ascoli Satriano, Puglia, focusing on the Archaic contexts.

Hedvig Landenius Enegren is a researcher affiliated with the Centre for Textile Research (CTR), University of Copenhagen, Denmark, where she 
was a Marie Curie Fellow 2012-2014. Her research spans topics from Aegean Late Bronze Age epigraphy (Linear B) and eastern Mediterranean epigraphy of the first millennium $\mathrm{BC}$ (Cypriot Syllabic) to ancient textiles and textile tool technology in central and southern Italy, Sicily and Cyprus. She is currently conducting research on the textile tools from the Swedish Institute in Rome excavations at the Etruscan sites of Acquarossa and San Giovenale, Italy and select textile remains on Bronze Age metal finds in the Cyprus Museum, Nicosia.

Francesco Meo is currently a Researcher and Adjunct Professor in the Department of Cultural Heritage, University of Salento, Italy. He is the Scientific Director of the Muro Leccese Archaeological Project, a Messapian indigenous settlement in the Puglia region of south Italy. His research focuses on the study of textile production in south Italy between the Iron Age and the Roman Empire and on the changes of Messapian indigenous society between the Iron Age and the arrival of the Romans in the third century BC.

\section{Classical Authors and Texts}

Athenaeus, The Learned Banqueters (Deipnosophistae).

\section{Abbreviation}

FGrH:

Jacoby, F.

1923 Fragmente der Griechischen Historiker I. Genealogie und Mythographie. Berlin: Weidmann.

\section{References}

Andersson Strand, E.B.

2013 The textile chaîne opératoire: using a multidisciplinary approach to textile archaeology with a focus on the Ancient Near East. Paléorient 38: 21-40. https://doi.org/10.3406/ paleo.2012.5456

2014 Sheep, wool and textile production, an interdisciplinary approach on the complexity of wool working. In C. Breniquet and C. Michel (eds.),
Wool Economy in the Ancient Near East and the Aegean: From the Beginnings of Sheep Husbandry to Institutional Textile Industry, 41-51. Oxford: Oxbow Books.

Andersson Strand, E.B., K.M. Frei, M. Gleba, U. Mannering, M.-L.B. Nosch and I. Skals

2010 Old textiles-new approaches. European Journal of Archaeology 13: 149-73. https://doi. org/10.1177/1461957110365513

Andersson Strand, E.B., M.-L. Nosch and J. Cutler

2015 Textile tools and textile production-studies of selected Bronze Age sites. Introduction. In M.-L. Nosch and E.B. Andersson Strand (eds.), Tools, Textiles and Contexts: Investigating Textile Production in the Aegean and Eastern Mediterranean Bronze Age, 191-96. Oxford: Oxbow Books.

Barber, E.J.W.

1991 Prehistoric Textiles: The Development of Cloth in the Neolithic and Bronze Ages. Princeton, New Jersey: Princeton University Press.

Barth, F.

1961 Nomads of South Persia: The Basseri Tribe of the Khamseh Confereracy. Oslo: Oslo University Press.

Bianco, S.

1999 La prima Età del Ferro. In D. Adamesteanu (ed.), Storia della Basilicata 1. L'Antichità, 13782. Bari: Laterza.

Bietti Sestieri, A.M.

1992 The Iron Age Community of Osteria dell'Osa: A Study of Socio-political Development in Central Tyrrhenian Italy. Cambridge: Cambridge University Press.

Bonfante, L.

2003 Etruscan Dress. 2nd edn. Baltimore: Johns Hopkins University Press.

Bottini, A.

1978 La ricerca archeologica nel Melfese. In Magna Grecia bizantina e tradizione classica, 431-35. Taranto: Arte Tipografica.

1979 Una nuova necropolis nel Melfese e alcuni problem del periodo arcaico nel mondo indigeno. Annali dell'Istituto Universitario Orientale di Napoli. Dipartimento di studi del Mondo Classico e del Mediterraneo Antico. Sezione di Archeologia e Storia Antica 1: 77-94.

1980 L'area melfese dall'età arcaica alla romanizzazione (VI-III sec. a. C.). In Attività Archaeologica in 
Basilicata 1964-1977. Scritti in onore di Dinu Adamesteanu, 313-44. Matera: Edizioni Meta.

1982 Il Melfese fra VII e V sec. a. C. Dialoghi di Archeologia n.s. 4: 152-60.

Braudel, F.

1996 [1939] The Mediterranean and the Mediterranean World in the Age of Philip II. 2 vols. Berkeley: University of California Press.

Carollo, G., and M. Osanna

2009 Organizzazione territoriale e produzioni ceramiche specializzate in area nord-lucana: Torre di Satriano e Ripacandida. In M. Bettelli, C. De Faveri and M. Osanna (eds.), Prima delle colonie. Organizzazione territoriale e produzioni ceramiche specializzate in Basilicata e in Calabria settentrionale ionica nella prima età del ferro, 383-419. Venosa, Italy: Osanna Edizioni.

Carpenter, T.H., K.M. Lynch and E.G.D. Robinson

2014 The Italic People of Ancient Apulia: New Evidence from Pottery for Workshops, Markets, and Customs. Cambridge: Cambridge University Press.

Carrer, F. https://doi.org/10.1017/CBO9781107323513

2015 Herding strategies, dairy economy and seasonal sites in the southern Alps: ethno-archaeological inferences and archaeological implications. Journal of Mediterranean Archaeology 28: 3-22. https://doi.org/10.1558/jmea.v28i1.27499

Carrier, E. $\mathrm{H}$.

1932 Water and Grass: A Study in the Pastoral Economy of Southern Europe. London: Christophers.

Catalli, E., M. Corrente, A. Di Giovanni, M.R. Giuliani, M.C. Laurenti and M. Pastorelli

2018 Spinning and weaving by Herdonia women. In A. Tricomi, M.S. Busana, M. Gleba and F. Meo (eds.), Purpureae Vestes VI. Valencia: University of Valencia Press.

Chen, H.L., K.A. Jakes and D.W. Foreman

1998 Preservation of archaeological textiles through fibre mineralization. Journal of Archaeological Science 25: 1015-21. https://doi.org/10.1006/ jasc. 1997.0286

Collingwood, P.

1996 The Techniques of Tablet Weaving. McMinnville, Oregon: Robin and Russ Handweavers.

Cutler, J.

2012 Ariadne's thread: the adoption of Cretan weaving technology in the wider southern Aegean in the mid-second millennium BC. In M.-L. Nosch and R. Laffineur (eds.), KOSMOS: Jewellery, Adornment and Textiles in the Aegean Bronze Age. Aegaeum 33: 145-54. Leuven: Peeters.

Donnellan, L.

2016 'Greek colonisation' and Mediterranean networks: patterns of mobility and interaction at Pithekoussai. Journal of Greek Archaeology 1: 109-48.

Donnellan, L., V. Nizzo and G.-J. Burgers (eds.)

2016 Contextualising early Colonisation II. Conceptualising early Colonisation. Brussels and Rome: Belgisch Historisch Instituut te Rome.

Ferdinand, K.

1969 Nomadism in Afghanistan: with an appendix on milk products. In L. Földes (ed.), Viehwirtschaft und Hirtenkultur. Ethnographische Studien, 12760. Budapest: Akadémiai Kiadó.

Gaastra, J.S.

2014 Shipping sheep or creating cattle: domesticate size changes with Greek colonisation in Magna Graecia. Journal of Archaeological Science 52: 483-96. https://doi.org/10.1016/j.jas. 2014.08.030

Garnsey, P.

1988 Mountain economies in southern Europe: thoughts on the early history, continuity and individuality of Mediterranean upland pastoralism. In C.R. Whittaker (ed.), Pastoral Economies in Classical Antiquity, 196-209. Cambridge: Philological Society.

Giorgi, M., S. Martinelli, M. Osanna and A. Russo (eds.)

1988 Forentum I. Le necropoli di Lavello. Venosa, Italy: Osanna Edizioni.

Gleba, M.

2008 Textile Production in Pre-Roman Italy. Oxford: Oxbow Books.

2011 The 'distaff side' of Early Iron Age aristocratic identity in Italy. In M. Gleba and H.W. Horsnæs (eds.), Communicating Identity in Italic Iron Age Communities, 26-32. Oxford: Oxbow Books.

2012 Italy: Iron Age. In M. Gleba and U. Mannering (eds.), Textiles and Textile Production in Europe from Prehistory to $A D$ 400, 214-41. Oxford: Oxbow Books.

2017a Textiles in Pre-Roman Italy: from qualitative to quantitative approach. Origini 40: 9-28.

2017b Tracing textile cultures of Italy and Greece in the early first millennium BC. Antiquity 144: 120522. https://doi.org/10.15184/agy.2017.144 
Gleba, M., and R. Laurito

2015 Appendice 1. Analisi delle tracce di tessuti rinvenuti a Grotte di Castro in località Vigna la Piazza. In G.M. Della Fina (ed.) La delimitazione dello spazio funerario in Italia dalla protostoria all'età arcaica recinti, circoli, tumuli, 337-39. Rome: Edizioni Quasar.

Gleba, M., I. Menale and C. Rescigno

2017 Cumaean cremation burials with textiles remains. Origini 40: 45-63.

Gleba, M., and I. Vanden Berghe

n.d. Textiles from Cumae Fondo Artiaco 104: structural and dye analyses. In A. Babbi, Cumae, Grave Artiaco 104: performative identity and transculturality in the Middle-Tyrrhenian region at the end of the 8 th c. BC. Jahrbuch des Römisch-Germanischen Zentralmuseums. Forthcoming.

Grömer, K., A. Kern, H. Reschreiter and H. RöselMautendorfer (eds.)

2013 Textiles from Hallstatt: Weaving Culture in Bronze and Iron Age Salt Mines. Textilien aus Hallstatt. Gewebte Kultur aus dem bronze- und eisenzeitlichen Salzbergwerk. Budapest: Archaeolingua.

Heitz, C.

2015 Ripacandida - an indigenous graveyard and the Greek periphery. Accordia Research Papers 14: 103-21.

2016 Von 'ganzen Häusern' zu großen Männern? Beobachtungen zu Veränderungen in der Struktur süditalischer Gemeinschaften in archaischer Zeit am Beispiel der Nekropole von Ripacandida/Basilicata. BABESCH: Annual Papers on Mediterranean Archaeology 91: 43-67.

2017 Mobile pastoralists in Archaic southern Italy? The use of social and material evidence for the detection of an ancient economy. EthnologischArchäologische Zeitschrift 56 (2015): 135-64.

2018 Die Nekropole von Ripacandida -Indigene Identitäten in Süditalien vom 7. bis zum 5. Jh. v. Chr. Italikà 6. Wiesbaden: Reichert.

Herring, E.

1998 Explaining Change in the Matt-Painted Pottery of Southern Italy: Cultural and Social Explanations for Ceramic Development from the 11th to the 4 th Centuries B.C. British Archaeological Reports, International Series 722. Oxford: Archaeopress. Hütteroth, W.-D.

1959 Bergnomaden und Yaylabauern im mittleren kur- dischen Taurus. Marburg: Selbstverlag des Geographischen Institutes der Universität.

Laimer, M., and A. Larcher

2006 Archäologische Ausgrabungen in der Giarnera Piccola in Ascoli Satriano (Provinz Foggia) 1999 und 2001-2005. Römische Historische Mitteilungen 48: 17-58. https://doi.org/10.1553/ rhm $48 \mathrm{~s} 17$

Landenius Enegren, H.

2015 Loom weights in Archaic South Italy and Sicily: five case studies. Opuscula: Annual of the Swedish Institutes at Athens and Rome 8: 123-55.

Landenius Enegren H., and I. Vanden Berghe

2016 Two 'rediscovered' textile fragments from Palaeoskoutella, Karpas peninsula. In C. Bourogiannis and C. Mühlenbock (eds.), Ancient Cyprus Today: Museum Collections and New Research. Studies in Mediterranean Archaeology and Literature Pocketbook 184: 187-94. Uppsala: Åströms Förlag.

Larcher, A., U. Töchterle and M. Laimer (eds.)

2018 La Daunia Ascolana dell'Università di Innsbruck. Diciotto anni di ricerca archeologica a Ascoli Satriano. Foggia, Italy: Grenzi.

Lave, J., and E. Wenger

1991 Situated Learning: Legitimate Peripheral Participation. Cambridge: Cambridge University Press. Liebmann, M. https://doi.org/10.1017/CBO9780511815355

2013 Parsing hybridity: archaeologies of amalgamation in seventeenth-century New Mexico. In J. Card (ed.), The Archaeology of Hybrid Material Culture. Center for Archaeological Investigations, Occasional Paper 39: 25-49. Carbondale: Southern Illinois University Press.

Luberto, M.R., and F. Meo

2017 Textile production along the Ionian coast of Calabria during the Archaic period: the example of Kaulonia. Origini 40: 233-48.

Meo, F.

2015 L'attività tessile a Herakleia di Lucania tra III e I secolo a.C. Fecit Te 7. Rome: Scienze e Lettere.

2018 Primi dati sulle produzioni tessili tarantine nel III-II secolo a.C. In M. Garcia and M. Gleba (eds.), Vetus Textrinum: Textiles in the Ancient World. Studies in Honour of Carmen Alfaro Giner, 153-64. Barcelona: University of Barcelona Press.

Mientjes, A.C.

2004 Modern pastoral landscapes on the island of 
Sardinia (Italy): Recent pastoral practices in local versus macro-economic and macro-political contexts. Archaeological Dialogues 10: 161-90. https://doi.org/10.1017/S1380203804001230

2010 Pastoral communities in the Sardinian highlands (Italy): a view on social mobility. Ethnos 75: 148-70. https://doi.org/10.1080/ 00141841003678759

Möller-Wiering, S.

2015 External examination of spinning and weaving samples. In E.B. Andersson Strand, M.-L. Nosch and J. Cutler (eds.), Tools, Textiles and Contexts: Investigating Textile Production in the Aegean and Eastern Mediterranean Bronze Age, 104-26. Oxford: Oxbow Books.

Nieling, J.

2007 Brettchengewebte Borten der späten Hallstattzeit in Prunkgrab von Hochdorf und auf den sog. Daunischen Stelen in Apulien. In S. Burmeister, H. Derks and J. Von Richthofen (eds.), Zweiundvierzig. Festschrift für Michael Gebühr zum 65 Geburtstag, 159-66. Rahden and Westfalen: Verlag Marie Leidorf.

Nijboer, A.J.

2011 Italy, its interconnections and cultural shifts during the Iron Age. In M. Dalla Riva and H. Di Giuseppe (eds.), Meetings between Cultures in the Ancient Mediterranean. Proceedings of the 17th International Congress of Classical Archaeology, Rome 22-26 September 2008. Special issue of Bollettino di Archeologia Online 0, F/F2/2: 1-22. Online: http://www.bollettinodiarcheologiaonline.beniculturali.it/documenti/generale/1_NIJ-

Olofsson, L. BOER.pdf

2015 An introduction to experimental archaeology and textile research. In E.B. Andersson Strand and M.-L. Nosch (eds.), Tools Textiles and Contexts: Investigating Textile Production in the Aegean and Eastern Mediterranean Bronze Age, 25-38. Oxford: Oxbow Books.

Pacciarelli, M.

1999 Torre Galli. La necropoli della prima età del ferro (Scavi Paolo Orsi 1922-23). Soveria Manelli (Catanzaro), Italy: Rubbettino Editore.

Petrocelli, E. (ed.)

1999 La civiltà della transumanza. Storia, cultura e valorizzazione die tratturi e del mondo pastorale in Abruzzo, Molise, Puglia, Campania e Basilicata. Isernia, Italy: Iannone.

Quercia, A.

2017 Textile production and technological changes in the Archaic societies of Magna Graecia: the case of Torre di Satriano (Lucania, Italy). Origini 40: 249-64.

Quercia, A., and L. Foxhall

2014 Temporality, materiality and women's networks: the production and manufacture of loom weights in the Greek and indigenous communities of southern Italy. In K. Rebay-Salisbury, A. Brysbaert and L. Foxhall (eds.), Knowledge Networks and Craft Traditions in the Ancient World: Material Crossovers. Routledge Studies in Archaeology 13: 62-81. London: Routledge.

Raeder Knudsen, L.

2012 The tablet-woven borders of Verucchio. In M. Gleba and U. Mannering (eds.), Textiles and Textile Production in Europe from Prehistory to $A D$ 400, 254-63. Oxford: Oxbow Books.

Robb, J.

1997 Female beauty and male violence in early Italian society. In A.O. Koloski-Ostrow and C.L. Lyons (eds.), Naked Truths: Women, Sexuality, and Gender in Classical Art and Archaeology, 43-65. London and New York: Routledge.

Russo, A. (ed.)

2006 Con il fuso e la conocchia. La fattoria lucana di Montemurro e l'edilizia domestica nel IV secolo a.C. Potenza, Italy: Ministero per i Beni e le Attività Culturali.

Russo, A., and H. Di Giuseppe (eds.)

2008 Felicitas Temporum. Dalla terra alle genti: la Basilicata settentrionale tra archeologia e storia. Potenza, Italy: Soprintendenza per i Beni Archeologici della Basilicata.

Santillo Frizell, B.

1996 Per itinera callium: Report on a pilot project. Opuscula Romana 21: 57-81.

Sauvage, C., and J.S. Smith

2016 Local and regional patterns of textile production in Late Bronze Age Cyprus. In C. Bourogiannis and C. Mühlenbock (eds.), Ancient Cyprus Today: Museum Collections and New Research. Studies in Mediterranean Archaeology and Literature Pocketbook 184: 195-205. Uppsala: Åströms Förlag. 
Scalici, M.

2009 Ruvo del Monte. La necropoli in loc. S. Antonio. Nuovi dati e prospettive di ricerca. Siris 10: 37-51.

Setari, E.

1999 Produzioni artigianali indigene. La 'fabbrica' di Ripacandida. Siris 1: 69-119.

Silliman, S.

2015 A requiem for hybridity? The problem with Frankensteins, purées, and mules. Journal of Social Archaeology 15: 277-98. https://doi. Spantidaki, S. org/10.1177/1469605315574791

2016 Textile Production in Classical Athens. Oxford: Oxbow Books.

Spantidaki, Y., and C. Moulhérat

2012 Greece. In M. Gleba and U. Mannering (eds.), Textiles and Textile Production in Europe from Prehistory to $A D$ 400, 185-200. Oxford: Oxbow Books.

Sprengel, U.

1971 Die Wanderherdenwirtschaft im mittel- und südostitalienischen Raum. Marburg: Selbstverlag des Geographischen Institutes der Universität.

Stauffer, A.

2012 Case study: the textiles from Verucchio, Italy. In M. Gleba and U. Mannering (eds), Textiles and Textile Production in Europe from Prehistory to $A D$ 400, 242-53. Oxford: Oxbow Books.

van Dommelen, P.

2005 Colonial interactions and hybrid practices:
Phoenician and Carthaginian settlement in the ancient Mediterranean. In G. Stein (ed.), The Archaeology of Colonial Encounters: Comparative Perspectives, 109-41. Santa Fe, New Mexico: School of Advanced Research.

2011 Postcolonial archaeologies between discourse and practice. World Archaeology 43: 1-6. https:// doi.org/10.1080/00438243.2011.544883

van Dommelen, P., and A.B. Knapp (eds.)

2010 Material Connections in the Ancient Mediterranean. Mobility, Materiality and Mediterranean Identities. London and New York: Routledge.

Vida Navarro, M.C.

1992 Warriors and weavers: sex and gender in Early Iron Age graves from Pontecagnano. Accordia Research Papers 3: 67-100.

Wendrich, W.

2012 Archaeology and apprenticeship: body knowledge, identity, and communities of practice. In W. Wendrich (ed.), Archaeology and Apprenticeship: Body Knowledge, Identity, and Communities of Practice, 1-19. Tuscon: University of Arizona Press.

Wenger, E.

1998 Communities of Practice: Learning, Meaning and Identity. Cambridge: Cambridge University Press. https://doi.org/10.1017/CBO9780511803932

Yntema, D.

1990 The Matt-Painted Pottery of Southern Italy. Galatina: Congedo Editore. 